Международная Объединенная Академия Наук

\title{
Научные тенденции: Педагогика и психология
}

\author{
Сборник научных трудов \\ по материалам \\ XXI международной научной конференции \\ 4 февраля 2019 г.
}

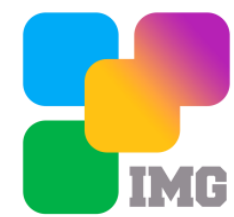

Санкт-Петербург 2019 
УДК 001.1

ББК 60

H34

«Научные тенденции: Педагогика и психология» Сборник научных трудов, по материалам международной научнопрактической конференции 4 февраля 2019 г. Изд. ЦНК МОАН, 2019. - 68c.

\section{SPLN 001-000001-0392-PP \\ DOI 10.18411/spc-04-02-2019 \\ IDSP sciencepublic-04-02-2019}

В сборнике научных трудов собраны материалы из различных областей научных знаний. $\mathrm{B}$ данном издании приведены все материалы, которые были присланы на XXI международную научно-практическую конференцию «Научные тенденции: Педагогика и психология»

Сборник предназначен для научных работников, преподавателей, аспирантов и студентов.

Все материалы, размещенные в сборнике, опубликованы в авторском варианте. Редакция не вносила коррективы в научные статьи. Ответственность за информацию, размещенную в материалах на всеобщее обозрение, несут их авторы.

Информация об опубликованных статьях будет передана в систему Российского индекса научного цитирования (РИНЦ) и наукометрическую базу SPINDEX

Электронная версия сборника доступна на сайте ЦНК MOAН. Сайт центра: conf.sciencepublic.ru

УДК 001.1

ББК 60 


\section{Содержание}

РАЗДЕЛ І. ПЕДАГОГИКА

Антипова Ю.В., Борзенкова О.А. Педагогические условия развития учебной мотивации младших школьников во внеурочной деятельности

Болтабоев С.А. Интеграция как способ формирования высокообразованной, интеллектуально развитой личности учащихся начальных классов

Буханцева Н.В. Информационно-аналитическая система как инструмент коммуникации в профессионально-образовательной среде.

Гонова Н.В., Винник В.К. Место и роль общеобразовательной организации в формировании человеческого капитала.

Даминова Ш.К. Самообразование - оптимальная форма повышения квалификации .. 19

Дрёмина С.Л., Демченко С.Г. Создание базовой переводческой компетенции студентов-не филологов

Каргиева О.Н. Практико-ориентированная образовательная деятельность в подготовке будущих учителей начальных классов

Лукьянова Д.Е., Назранова К.А. Взгляды Е.Н. Медынского на проблему внешкольного образования в России

Матвеева Е.С. Внешняя среда образовательной организации как объект управления. 29

Михайлов Н.Г., Кавокин А.И. Оптимизация двигательной активности детей $5-7$ лет в дошкольной образовательной организации. 31

Поляруш А.А. От индустрии знаний - к методу познания. 34

Скрынников Н.П. Кодекс чести офицера: история и направления развития 37

Старостина А.Н. Начертательная геометрия как феномен человеческой культуры ..... 41

Тюнькова И.А. Организация и проведение краеведческих игр со школьниками.

Ушакова И.А. Управление психоэмоциональным состоянием иностранных студентов средствами физической культуры

Хмелевская Я.А. Учебная мотивация как один из критериев эффективности учебного процесса 50

Ширинов М.К. Специфические особенности дидактических принципов в совершенствовании взаимосвязанности и непрерывности преподавания предмета "Природоведение". .56 
РАЗДЕЛ ІІ. ПСИХОЛОГИЯ

Баринова Е.В. Методы психической саморегуляции

Пчелинцева Д.Г. Формирование нравственности у подростка к этнокультурному наследию в современных условиях на уроках иностранного языка 60

Садриддинов C.P. Концепт психологическая защита: теоретико-практический аспект. 62 


\section{РАЗДЕЛ І. ПЕДАГОГИКА}

\section{Антипова Ю.В. ${ }^{1}$, Борзенкова О.А. ${ }^{2}$ \\ Педагогические условия развития учебной мотивации младших школьников во внеурочной деятельности}

${ }^{1}$ ГБОУ СОШ № 2

(Россия, Самарская обл., с. Приволжье)

${ }^{2}$ Самарский государственный сочиально-педагогический университет (Россия, Самара)

doi 10.18411/spc-04-02-2019-01

idsp sciencepublic-04-02-2019-01

\section{Аннотация}

Проблема повышения уровня образовательного процесса в начальной школе всегда остается актуальной. Развитие учебной мотивации младших школьников является одной из основных проблем современной школы. Внеурочная деятельность способствует развитию мотивации к учению младших школьников.

Цель статьи - обосновать некоторые педагогические условия развития учебной мотивации обучающихся во внеурочной деятельности.

В статье обоснованы некоторые методические приемы развития учебной мотивации детей.

Ключевые слова: внеурочная деятельность; мотивация к учению; формы внеурочной деятельности; методы и приемы развития учебной мотивации; принципы организации внеурочной деятельности; педагогические условия.

Значимым направлением Федерального государственного образовательного стандарта начального общего образования (далее - ФГОС НОО) является развитие положительной учебной мотивации обучающихся как важного условия обеспечения качества образования [11].

Проблема развития мотивации к учению является важной в психологопедагогических исследованиях. Обозначенный аспект нашел широкое применение также в философии, социологии, психологии.

Теоретическое обоснование указанной проблемы рассматривалась в трудах Ю.В. Антиповой, В.Г. Асеева, И.А. Зимней, Е.П. Ильина, А.К. Марковой, А. Маслоу, А.Б. Орлова, С.Л. Рубинштейна, В.И. Смирнова, Л.М. Фридмана и др.

Е.П. Ильин, А.Н. Леонтьев, А Маслоу, Е.Е. Насиновская, П.М. Якобсон и др. изучали психологические аспекты мотивации учения.

В некоторых исследованиях обозначен механизм возникновения учебных мотивов, а также обоснована роль мотивации в осуществлении учебной деятельности (труды Л.И. Божовича, И.М. Вереникиной, Л.С. Выготского, А.К. Марковой, Е.И. Савонько, Н.М. Симоновой, М.В. Матюхиной, Л.М. Фридмана, Г.И. Щукиной и др.).

Педагогические условия развития учебной мотивации обучающихся в начальной школе не нашли должного освещения в указанных источниках. Рассмотрим понятие «мотивация».

В педагогической литературе под мотивацией (от латинского movere «двигаю») понимается общее название для процессов, средств побуждения обучающихся к продуктивной познавательной деятельности, активному усвоению содержания образования $[3 ; 4 ; 5 ; 7 ; 10]$.

Итак, с позиции обучаемого следует вести речь о мотивации учения (И.П. Подласый). 
Мотивация - побуждение к действию; важными признаками выступают направленность, организация, активность и устойчивость [9].

Учебная мотивация - частный вид мотивации, включенный в учебную деятельность и определяющий потребности обучающихся в получении знаний (Н.М Симонова, Е.И. Савонько).

А.К. Маркова, изучая проблему формирования мотивации учения, рассматривает ее как осознанное внутренне побуждение к учению, придающее ему тот или иной личностный смысл [7, с.12-18].

Учебная мотивация системна; важные характеристики: направленность, устойчивость, динамичность.

Мотивационная сфера - сложная динамическая система. В структуру мотивационной сферы входят: потребность в учении $\Leftrightarrow$ сущность учения $\Leftrightarrow$ мотив учения $\Leftrightarrow$ цель эмоции $\Leftrightarrow$ отношение $\Leftrightarrow$ интерес (А.К. Маркова).

Развитие учебной мотивации включает в себя два механизма:

- механизм «снизу - вверх» (организация педагогом условия деятельности);

- механизм «сверху - вниз» (интериоризация ребенком предъявляемых ему в готовом виде целей, идеалов и др.) (А.К. Маркова).

Основным видом деятельности младшего школьника является учебная деятельность. В процессе этой деятельности происходит развитие всех психических процессов личности ребенка. Развитию учебной мотивации способствует правильно организованная педагогом внеурочная деятельность.

Внеурочная деятельность детей - вариативная часть базисного учебного плана (экскурсии, кружки, круглые столы, конференции, диспуты, школьные научные общества, олимпиады, соревнования и др.) [5, с.38].

Внеурочная деятельность обучающихся объединяет все виды деятельности детей (кроме учебной деятельности), в которых решаются задачи воспитания и развития [2, с.14].

Внеурочная деятельность является основой образования, направлена на осуществление преемственности общего и дополнительного образования [3, с.17].

Развитие мотивации предполагает создание педагогических условий для появления внутренних побуждений к обучению [12, с.128].

И.П. Подласый обосновал некоторые педагогические условия, способствующие развитию учебной мотивации:

- обогащать содержание интересным материалом;

— удовлетворять познавательные запросы и потребности обучающихся;

— организовать общение детей между собой;

— поощрять выполнение заданий повышенной трудности;

- поддерживать ровный стиль отношений между всеми детьми;

- развивать активную самооценку своих возможностей;

- утверждать стремление к саморазвитию, самосовершенствованию;

- использовать эффективную поддержку детских инициатив, ободрять детей при возникновении у них трудностей;

— воспитывать ответственное отношение к учебной деятельности и др. [9, c.52].

Анализ программ организации внеурочной деятельности обучающихся позволил выделить следующие принципы:

- непрерывное дополнительное образование как механизм обеспечения полноты образования в целом;

- развитие индивидуальности каждого ребенка;

- целостность партнерских отношений всех субъектов дополнительного образования;

- системная организация управления процессом обучения [6, с.69]. 
Обучение является ведущим видом деятельности для младших школьников, именно поэтому следует искать пути развития учебной мотивации.

Педагог начальной школы обязан ориентироваться во всем многообразии методов и приемов обучения, уметь четко их отбирать и сочетать $[8$, с.12].

Например, использование ИКТ во внеурочной деятельности, способствует повышению уровня развития мотивации к учению у младших школьников; перейти к деятельностному способу обучения.

Применение ИКТ во внеурочной деятельности позволяет развивать умение обучающихся ориентироваться во всем многообразии потоке информации, овладевать практическими способами работы с различной информацией и др. мотивации.

Целесообразно, на наш взгляд, рассмотреть методы и приемы развития учебной

В.И. Смирнов в своих исследованиях рассматривает следующие методы развития мотивации учения [10].

Методы развития учебной мотиващчи младших икольников

Таблица 1

(Источник: В.И. Смирнов)

\begin{tabular}{|c|c|}
\hline \multicolumn{2}{|c|}{$\begin{array}{c}\text { Методы развития учебной мотивации } \\
\text { (методы стимулирования и мотивации учебно-познавательной деятельности) } \\
\text { (по В.И. Смирнову) }\end{array}$} \\
\hline методы стимулирования интереса к учению & методы стимулирования долга и ответственности \\
\hline $\begin{array}{ll} & \text { познавательные игры; } \\
\bullet & \text { учебные дискуссии; } \\
\text { • } & \text { создание ситуаций занимательности; } \\
\text { • создание ситуаций успеха }\end{array}$ & $\begin{array}{l}\text { • } \\
\text { лормирование убеждения в социальной и } \\
\text { личностной значимости учения; } \\
\text { • } \\
\text { • } \quad \text { предъявление требований; } \\
\text { требований; } \\
\text { • } \\
\quad \text { пожщрения, наказания }\end{array}$ \\
\hline
\end{tabular}

Приемы развития учебной мотивации младших школьников отражены в таблице $2[4$, c.21-67].

Таблица 2

Приемы развития учебной мотивации младших школьников

(Источник: М.Р. Гинзбург, Л.М. Фридман)

\begin{tabular}{|c|c|}
\hline прием & краткая характеристика \\
\hline «Привлекательная цель» & $\begin{array}{c}\text { Перед детьми ставится простая цель, младшие школьники выполняют то } \\
\text { учебное действие, которое планирует педагог. }\end{array}$ \\
\hline «Оратор» & $\begin{array}{c}\text { Обучающемуся следует за установленное время убедить своего } \\
\text { собеседника в необходимости знаний по данной теме. }\end{array}$ \\
\hline «Автор» & $\begin{array}{c}\text { Детям предлагается побыть в роли автора учебника и предложить свой } \\
\text { вариант объяснения одноклассникам в необходимости изучения выбранной } \\
\text { темы. }\end{array}$ \\
\hline «Профи» & $\begin{array}{c}\text { Младшим школьникам предлагается «заглянуть» в будущую профессию и } \\
\text { обосновать необходимость изучения конкретной темы. }\end{array}$ \\
\hline «Лови ошибку» & $\begin{array}{c}\text { Учитель в процессе объяснения материала намеренно допускает ошибку } \\
\text { (или неточность). Младшие школьники знают об этом заранее. Задача детей } \\
\text { - найти ошибку, наметить пути ее исправления. }\end{array}$ \\
\hline «Свободное задание» & $\begin{array}{c}\text { Педагог предлагает обучающимся ряд необязательных заданий, } \\
\text { предупредив, что их выполнение лишь желательно, но полезно, например, } \\
\text { для более глубокого освоения учебного материала. Оценки за выполнение } \\
\text { такого задания (или заданий) не ставятся. Выполнение подобных заданий } \\
\text { свидетельствует о внутреннем интересе школьников к данному учебному } \\
\text { предмету. }\end{array}$ \\
\hline
\end{tabular}

Рассмотренные направления развития

мотивации к учению младших школьников позволили обосновать ряд приемов: 
- наличие материала с опорой на усвоенное знание и практический опыт деятельности ребенка [1, с.89-95];

- создание проблемной ситуации, где школьник действует активно, вовлекается в процесс самостоятельного поиска и «открытия» новых знаний;

- разнообразие учебной деятельности младшего школьника (продуктивная, творческая, исследовательская деятельности);

- использование игровых ситуаций (эффект неожиданности);

- яркость, эмоциональность, доступность учебного материала;

- использование современных информационных ресурсов, активных методов обучения и др.

Данные методы и приемы способствуют развитию учебной мотивации обучающихся; применять их можно также и в учебном процессе детей.

$$
* * *
$$

1. Борзенкова О.А., Антипова Ю.В. Методические условия развития познавательного интереса младших школьников во внеурочной деятельности. // Детство как антропологический, культурологический, психолого-педагогический феномен: Материалы III Международной научной конференции. Самара, 24-25 марта 2017 года. В рамках проекта «А.З.Б.У.К.А. детства». Часть 2. / Отв. ред.: Т.А. Чичканова. Самара: СГСПУ; ООО «Научно-технический центр», 2017. 348 с. С. 89 95.

2. Борзенкова О.А., Антипова Ю.В. Педагогические условия развития интереса младших школьников к изучению математики во внеурочной деятельности. // Продуктивное обучение: опыт и перспективы. Сборник материалов IX международной научной конференции Артемовские чтения.(оргкомитет: С.П. Зубова (пред.) и др. Казань: Изд-во «Бук», 2017. 214 с. С.14-16.

3. Власова Н.Н. Изучение особенностей доминирования мотивов у детей младшего школьного возраста. / Н.Н. Власова. М.: Просвещение, 2007. 50 с.

4. Гинзбург М.Р. Развитие мотивов учения у детей 6-7 лет. / Под ред. Д.Б. Эльконина, Л.А. Венгер. М.: Просвещение, 1988. 136 с.

5. Коджаспирова Г.М., Коджаспиров А.Ю. Словарь по педагогике. М.: ИКД Март, 2009. 106 с.

6. Львов М.Р. и др. Методика преподавания русого языка в начальных классах: Уч. пос. для студ. высш. пед. учеб.заведений. М.: Академия, 2002. 464 с.

7. Маркова А.К., Орлов А.Б., Фридман Л.М. Мотивация учения и ее формирование у школьников. М.: Педагогика, 1983. 64 с.

8. Педагогическая психология: Учеб. для студ. высш учеб заведений. / Под ред. Н.В. Клюевой. М.: ВЛАДОС-ПРЕСС, 2003. 400 с.

9. Подласый И.П. Педагогика начальной школы. / И.П. Подласый. M.: Просвещение, 2001.89 с.

10. Смирнов В.И. Общая педагогика. Учебное пособие. М.: Логос, 2002. 304 с.

11. Федеральный государственный образовательный стандарт начального общего образования: текст с изм. на 2011 г. М.: Просвещение, 2011. 33 с. [Электронный ресурс] режим доступа: <http://standart.edu.ru/catalog.aspx?CatalogId=959> 29.09.2018.

12. Хекхаузен Х. Мотивация и деятельность: учебное пособие. / 2003. 855 c.

Х. Хекхаузен. М.: Речь,

Болтабоев С.А.

Интеграция как способ формирования высокообразованной, интеллектуально развитой личности учащихся начальных классов

имени Низами ТГПУ

doi 10.18411/spc-04-02-2019-02

idsp sciencepublic-04-02-2019-02

В условиях бурного роста научно-технической информации, возрастающего накопления эмпирического и теоретического материала наблюдается неизбежный процесс дифференциации научных знаний, возникновения всё новых научных дисциплин. Углубляющаяся дифференциация наук объективно порождает необходимость противоположного процесса - интеграции научного знания. Эти два 
процесса неразрывно связаны, т.к. развитие техники, технологии производства во многом зависит не только от успехов отдельных отраслей науки, но и от междисциплинарного синтеза, интеграции их достижений. Поэтому интеграция наук, научных знаний должна находить своё отражение в образовании и обучении, а ориентация современного образования на целостность и фундаментализацию его содержания, предполагает создание интегрированного процесса обучения.

Введение интеграции в обучение соответствует новым социальным запросам, предъявляемым сегодня школе - формирование высокообразованной, интеллектуально развитой личности с целостным представлением картины мира, с пониманием глубины явлений и процессов, представляющих данную картину. Однако предметная разобщённость может стать одной из причин фрагментарности мировоззрения выпускника школы, в то время как в современном мире преобладают тенденции к экономической, политической, культурной, информационной интеграции. Таким образом, самостоятельность предметов, их слабая связь друг с другом порождают серьёзные трудности в формировании у учащихся целостной картины мира, препятствують органичному восприятию культуры.

Учитывая это, при разработке базисного учебного плана Государственного Образовательного Стандарта общего среднего образования Республики Узбекистан нашла своё отражение интеграция близких по содержанию учебных предметов по образовательным областям государственного компонента. Необходимость соответствия обучения Государственному Образовательному Стандарту делает проблему интеграции ещё более важной и современной. Особенно актуальна проблема интеграции обучения в начальной школе, когда один учитель ведёт все предметы.(4-8)

Интеграция в начальном, обучении позволяет пройти от локального, изолированного рассмотрения различных явлений действительности к их взаимосвязанному, комплексному изучению.

С учётом возрастных особенностей младших школьников при организации интегрированного обучения появляется возможность показать мир во всём его многообразии с привлечением научных знаний, литературы, музыки, живописи, что способствует эмоциональному развитию личности ребёнка и формированию его творческого мышления.

Благодаря интеграции обучения ученики начинают активно применять свои знания на практике, потому что знания легче обнаруживают свой прикладной характер, и учитель по-новому видит и раскрывает свой предмет, яснее осознавая его соотношение с другими науками.

Интеграция обучения позволяет уже в начальной школе заложить основы целостного представления о природе и обществе и сформировать собственное отношение к законам их развития. Кроме этого интегрированные уроки способствуют повышению интереса учащихся к учебному процессу. Проблема интеграции нашла свой отклик в трудах многих учёных-методистов (Р.А. Мавляновой, М.Г. Львова, В.Г. Горецкого, Н.Н. Светловской, Г.Н. Приступы, Макухиной И.В.) дидактов (И.Д. Зверева, Г.Ф. Федорца, В.Н. Максимовой) учёных-психологов (Е.Н.. КабановойМеллер, Ю.А. Самарина, Г.И. Вергелиса).

На сегодняшний день ни в одном словаре или справочнике нет методического значения слова «интеграция». Зато хорошо известно, что оно произошло от латинских слов - integratio - восстановление, восполнение, соединение и от inter - целый.(21). Из этого мы получаем определение понятия интеграции.

Интеграџия- это процесс развития, результатом которого является достижения единства и целостности внутри системы, основанной на взаимозависимости отдельных специализированных элементов.(6)

В чем же заключается суть интеграции в обучении? 
Применительно к системе обучения понятие «интеграция» может принимать два значения:

1) это создание у школьника целостного представления об окружающем мире (здесь интеграция рассматривается как цель обучения).

2) это нахождение общей платформы сближения предметных знаний (здесь интеграция - средство обучения).(9)

Особое значение имеет вопрос об уровнях интеграции. Она может быть весьма значительной, глубокой, характеризуемой новообразованием, полным слиянием разнохарактерного содержания значительных объёмов учебного материала.

В современной школе интеграция идёт по нескольким направлениям и на разных уровнях. Отметим эти уровни:

— внутрипредметный

- межпредметный (15)

Межпредметная интеграция может тесно сочетаться и с внутрипредметной интеграцией, образуя единое научное поле. Внутрипредметная интеграция направлена, прежде всего, на «спрессование» материала в крупные блоки и приводит к изменению структуры учебного дня (день математики, день литературы). Основанная на образовательной области межпредметная интеграция в состоянии существенно обогатить внутрипредметную интеграцию.(44)

В. Т. Фоменко тонко заметил, что характерные для современного образования процессы гуманизации, информатизации, экологизации, регионализации - не что иное, как интеграционные процессы.

Но педагогам следует иметь в виду, что в интеграции начального обучения и воспитания существуют благоприятные и неблагоприятные факторы. Эти факторы во многом определяют тактику интеграции. Колягин Ю.М. и Алексенко О.Л. отметили неблагоприятные факторы интеграции(14):

\section{1. Ограниченное число учебных предметов.}

Но это ограничение можно компенсировать тем, что содержание большого объема усваиваемых знаний должно отражать действительную картину мира, взаимозависимость её частей.

2. Необходимость формирования чрезвычайно важных навыков чтения, письма и счета.

Это, казалось бы, требует попредметного обучения. Однако даже традиционный опыт обучения чтению и математике, свидетельствует о широких интеграционных возможностях, которые можно еще и усилить. Так, чтение как предмет включает, помимо литературных текстов, материалы по истории, природоведению. Математика содержит арифметический, геометрический и алгебраический материал. Такая интеграция не только не мешает формированию важнейших навыков, но и является их гарантом. Роберт Карилас считает, что начальная школа может и должна сделать нечто более важное и существенное, чем просто обучить чтению, письму и счету, так как стимулирование интеллектуальной активности в период формирования любого ребенка имеет такое же значение для его последующих успехов, как и природные способности.

3. Трудность изложения интегрированных курсов так, чтобы детям данного возраста было понятно и интересно.

Мы считаем, что пути преодоления этого фактора лежат в области разработки оптимальных методик, выверенных практикой обучения, а также в специальной системе подготовки учителя.

Обобщив всё выше сказанное, мы можем предложить следующие варианты функционирования учебного процесса на интегративной основе:

- Интегрированный курс формируется из содержания предметов, входящих в одну и ту же образовательную область. При этом удельный вес одного 
предмета не превалирует над содержанием другого; обе научные дисциплины выступают на паритетных началах.

- Интегрированный курс создаётся из содержания дисциплин, входящих в одну и ту же область или один и тот же образовательный блок, но на базе преимущественно какой-то одной предметной области.

- Интегрированный курс создаётся из содержания дисциплин, входящих в различные, но близкие образовательные области и выступающих «на равных».

- Интегрированный курс создаётся на основе дисциплин из близких образовательных областей, но один предмет сохраняет свою специфику. А другие выступают в качестве вспомогательной основы.

- В интегративной связи находятся предметы взаимно удаленных образовательных областей и блоков, что присуще чаще всего вариативной части учебного плана и базируется на симультанном мышлении.

Интеграция позволяет увеличить темп изложения учебного материала, что концентрирует внимание учащихся и стимулирует их познавательную деятельность. Интегрированное обучение также позволяет учителю дать больший объём учебного материала за меньшее время. Система контроля при этом существенно облегчается.

Очень часто учителя используют интеграцию не на всём уроке, а только на каком-либо его этапе, т.е. интегрированным выступает только определённый фрагмент урока. Мы приводим фрагмент разработанного нами такого интегрирования по программе 3-го класса.

Решив, что эффективней широко применять сведения природоведческого характера во время словарной работы, так как те, или иные слова можно растолковать и с точки зрения лингвиста, и с точки зрения натуралиста, мы интегрировали предметы «русский язык» и «природу».

\section{Словарный диктант.}

У. «Из перечисленных мною животных вы выпишите в первый столбик названия диких, а во второй - домашних. Выделите в словах изученные орфограммы.

Белка, ёж, лошадь, кролик, заяц, лиса, коза, баран, барсук, бобр, лось, корова, медведь, бык.

При проверке словарного диктанта, учитель спрашивает: «Почему вы отнесли данное животное к диким (домашним)?

Нередко учителя интегрируют три учебных предмета. В нашем случае к предметам русский язык и природоведение добавляется еще один - изобразительное искусство. Мы применили такое интегрирование в 3- классе на занятии родного языка.

Тема: Весна на картине П. Кончаловского «Сирень».

Урок строится в такой последовательности:

1. «Перед вами репродукция картины П. Коналовского «Сирень», - обращается учитель к детям, - не правда ли, на вас сразу пахнуло весной? Рассмотрите внимательно картину. Обратите внимание на обилие цветов, изображённых художником. Сумел ли он показать, что сирень свежая? Как будто её только что срезали и принесли в комнату? Какого цвета эта пышная, великолепная сирень? Посмотрите, тщательно ли выписывает художник лепестки, веточки сирени? Почувствовали ли вы восхищение художника щедрой, богатой природой, его огромную любовь к ней? В природе, а точнее в сирени, он видит прекрасное, он видит в ней жизнь»

2. Далее по опорным словам, записанным на доске (богатый, щедрый, обильный, пышная, благоухает, сиреневый воздух, лиловые, синие, оранжевые, гроздья), дети пишут свои рассказы или мини-сочинения по картине.

3. Знакомство детей с легендой появления сирени: «Весна, смешав лучи солнца и радуги, стала бросать их на землю. И там, куда падали лучи, распускались цветы - 
жёлтые, оранжевые, красные, белые, синие. Весна шла с юга на север, щедро рассыпая свои лучи. Когда же она достигла севера, у неё остались одни только лиловые. Из нихто и выросли кусты сирени».

O проблемах интеграции школьного обучения в последнее время довольно много и часто говорят и пишут. Ученые и учителя - практики задумываются над тем, как формировать у детей целостное представление о мире, как создать общую платформу сближения предметных знаний. На сегодняшний день перед педагогами стоит ряд нерешённых проблем, главными из которых являются:

Как интегрировать?

Какой материал конкретного содержания отобрать для урока?

Нужно отметить, что изучению проблемы интеграции приступили именно учителя-практики, которые высказывают свои мнения по этому вопросу на страницах печати. В этом есть положительный факт для развития интеграции, т.к. в споре рождается истина.

$$
* * *
$$

1. Русский язык в начальных классах/ М.С. Соловейчик, П.С. Жедек, Н.Н.

2. Р.А.Мавлонова интеграция начального образования, учебное пособие, ТГПУ 2008 г

3. В.М. Кожуховская, Р.Ф. Исангулова, В.М. Несговорова. Путешествие в мир слов. Книга для чтения в 4 классе, - Ташкент, 2007.

\section{Буханцева Н. В. \\ Информационно-аналитическая система как инструмент коммуникации в профессионально-образовательной среде}

Волгоградский государственный университет

(Россия, Волгоград)

doi 10.18411/spc-04-02-2019-03

idsp sciencepublic-04-02-2019-03

\section{Аннотация}

Задача стимулирования интеграционных процессов в профессиональнообразовательной среде решается путем разработки информационно-аналитической системы научно-образовательного портала знаний с самоорганизующейся структурой базы данных, позволяющей реализовать механизм распределенного управления контентом.

Ключевые слова: микропортал, самоорганизация, портал, иерархический граф, контент, база данных, поисковая система.

\section{Abstract}

The task of promoting integration processes in the professional educational environment is solved by developing an information and analytical system of a scientific and educational knowledge portal with a self-organizing database structure that allows for implementation of a distributed content management mechanism.

Keywords: microportal, self-organization, portal, hierarchical graph, content, database, search facility.

Для стимулирования интеграционных процессов в образовательной системе предлагается разработка проекта информационной системы научно-образовательного портала знаний с самоорганизующейся структурой базы данных.

Для реализации децентрализованной системы необходимо пройти три основные ступени развития. Корпоративность первого уровня означает, организационную, функциональную, технологическую и информационную опору, 
главным образом, на образовательную структуру. Следующий уровень - открытая архитектура информационного пространства, т.е. привлечение на портал других научно-образовательных организаций следующего уровня. Третий этап - превращение портала в корпоративный портал единой научно-образовательной системы с элементами авторской экспертизы размещаемого информационного ресурса. Структура информационного пространства портала построена по фрактальному принципу. Функциональность работы портала обеспечивается системой управления базой данных, значительным количеством признаков информационного ресурса и развитой поисковой системой.

Основа поисковой системы, образующая главное структурное свойство портала - деятельностный подход - обеспечивает переход к следующим уровням его развития - портала для совместной работы и портала знаний. Ядро поисковой системы портала, существующей в виде поисковой системы базы данных и навигационной системы, составляет фрейм: «Субъект деятельности», «Вид деятельности», «Объект деятельности».

Субъектом деятельности является автор ресурса, им может быть как структурная единица организации, сама организация, так и личность, фактически являющаяся автором ресурса. Виды деятельности определяются стратегическим направлением образовательных организаций. Эти виды могут декомпозироваться в соответствующие им подвиды, например, тематические разделы. Объекты деятельности представляют собой адресные группы, для которых ресурс создается. Критерии подобной структуризации ресурса определяются автором и одновременно экспертом.

Фактическая структура фреймовых предикатов определяется динамически пополняемыми справочниками базы данных. Информационная структура самих справочников является также динамической. С каждым фреймом связан набор ресурсов базы данных (статья, монография, учебное пособие, диссертация, и т.д.), представляющую инфраструктуру пользователя. Дальнейшее усложнение поисковой системы (усложнение структуры справочников) позволит достичь уровня сложности портала знаний.

Децентрализация портала, означает самостоятельность субъекта деятельности разных уровней в развитии своего информационного ресурса (микропортала) (фактически, каждый фрейм представляет собой вход в микропортал т.е. единицу структуры с соответствующим ей признаком информационного ресурса, размещаемого в базу данных автором), достигаемую единством соответствующих программных средств и правил администрирования. Как уже отмечалось, фактически достигнутая степень децентрализации определяется различием признаков ресурсов в микропорталах. Высшая стадия развития портала - превращение его в корпоративный портал образовательной среды - связана с сетевой организацией его серверной и телекоммуникационной баз, структура которой будет соответствовать сетевой структуре самой региональной системы образования, т.е. родителем дочерних образовательных структур с горизонтальными связями, фактически, представляющая распределенную, открытую информационную систему.

Модель информационной структуры портала. Основа построения модели портала представлена деятельностной триадой, которая определяется принципом динамичности развития самой организации: каждый авторский информационный ресурс системы связан с определенным видом деятельности и направлен определенной тематической группе или личности (рис.1).

Каждый элемент триады представляет собой иерархический граф, хотя общая картина сложнее, чем просто дерево, множественное подчинение вершин графа определяет его сетевую структуру. В момент размещения информационного ресурса в базе данных он автоматически появляется в соответствующем тематическом разделе (микропортале), если раздел не существовал до появления ресурса (организуется новый 
раздел), шаблон страницы активизируется автоматически. Доступ к ресурсу может быть организован с нескольких направлений, прописанными признаками.

Например, ресурс «Иванов» при размещении в базу данных с признаками «научное направление X1», для студентов физиков будет активным в соответствующих ему тематических разделах (рис.1).

Удаление всей информации из раздела (это право автором ресурсов), раздел удаляется из инфраструктуры базы.

Множество микропортала с одним и тем же элементом триад и все подчиненные им микропорталы образуют структуру данного элемента триады (микропортал ВолГУ, микропортал факультета, микропортал автора ресурса, микропортал учебной работы, микропортал научного направления, микропортал студента и т.д.).

Администратор портала отслеживает возможные погрешности размещения и вносит коррективы (задача не допустить конфликтное множество вершины графа). Администратор микропортала (администратором микропортала может стать любой авторизованный пользователь или, в развитии структуры управляющий модуль программы) может самостоятельно проектировать иерархическую структуру каждого из триадных элементов соответствующего микропортала. Это означает, что не существует единой иерархической структуры триадных элементов.

Функции портала. В портале организованы три основные функции размещение, изменение и поиск ресурсов: размещение (изменение) ресурса в базе данных для авторизованных пользователей; поиск ресурса по базе данных по параметрам (по одному или группе), например: инициалам автора, инициалам персоналий, названию ресурса, виду ресурса, виду деятельности, организации, отделу, дисциплине, разделу науки, научному аппарату, ключевому слову (словам) и т.д., стандартные функции веб-структуры; копирование файлов из базы данных на локальный компьютер; отправка сообщений автору ресурса; размещение списка полезных ссылок для разных категорий пользователей - справочники, энциклопедии, списки организаций, т.д.; форумы (по факультетам, по направлениям научной деятельности, по дисциплинам и т.д.); анкетирование по различным проблемам (результаты анкетирования являются закрытой информацией); предоставление возможностей по конструированию веб-структур; услуги почтового сервиса.

\section{Самоорганизующаяся структура портала}

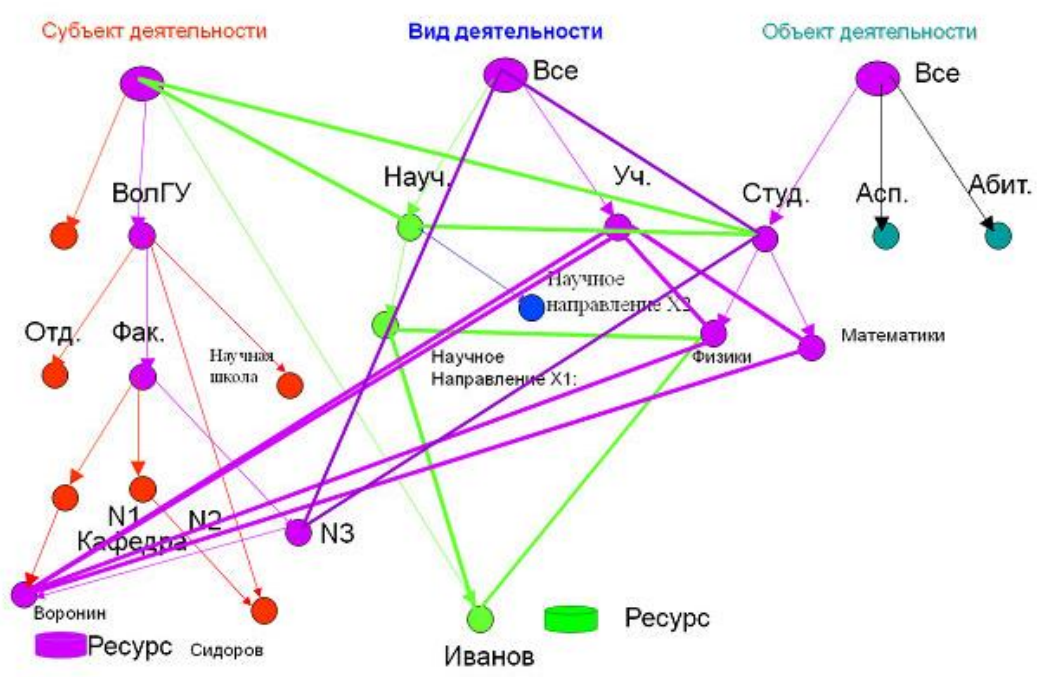

Рис.1. Модель портала знаний.

Любой пользователь, который размещает ресурс в базе данных портала становится Автором. Каждому Автору портала присваивается логин и пароль. Автор 
заполняет личные данные. Каждый размещаемый ресурс (перечень ресурсов в разделе «Перечень ресурсов») должен быть прописан. Полнота описания ресурса влияет на возможности поиска этого ресурса по присвоенным параметрам. Автор может никак не описывать ресурс, тогда найти данный ресурс будет можно только по фамилии автора.

Структурная схема портала. Структура портала построена по фрактальному принципу. Адресные группы - виды деятельности - организации - ресурсы.

Поисковая система представляет собой совокупность поисковой системы базы данных и навигационной системы портала. Каждый раздел портала представляет собой вход в микропортал, построенный по типовой структуре.

Структурная схема портала представляет собой два блока: блок поиска ресурсов и блок размещения и редактирования ресурсов (рис.2.). Поиск ресурса может быть как по ключевым словам, так и по авторским признакам в разном сочетании. Размещение, удаление и редактирование информации прерогатива автора. При размещении ресурса выполняется ряд условий: (рис.3)

1. Зарегистрироваться на портале в качестве АВТОРА ресурса;

2. Выбрать или добавить нужные признаки ресурсу, например:

- автор (вноситель) ресурса - фамилия, инициалы автора.

— вид деятельности (для ресурса) - научная статья

- адресные группы, для которых ресурс предназначен - аспиранты.

3. Заполнить анкету ресурса на соответствующей странице портала.

Структура базы данных. Основные принципы построения базы данных портала. База данных содержит таблицы трех видов: справочники, таблицы ресурсов, таблицы связей.

Справочники - таблицы, в которых вносятся значения, наиболее часто употребляемые для описания параметров ресурсов (города, организации, дисциплины и т.п.). Справочники имеют гораздо меньшее количество записей, чем другие таблицы. Справочники могут иметь линейную структуру или многоуровневую. Некоторые справочники заполняются только администратором.

Таблицы ресурсов - документов - база данных, в которую заносятся ресурсы представляющие из себя тексты. Это таблицы, которые имеют неограниченное количество записей (ограничение только по физическим возможностям сервера). Такие таблицы заполняются пользователями.

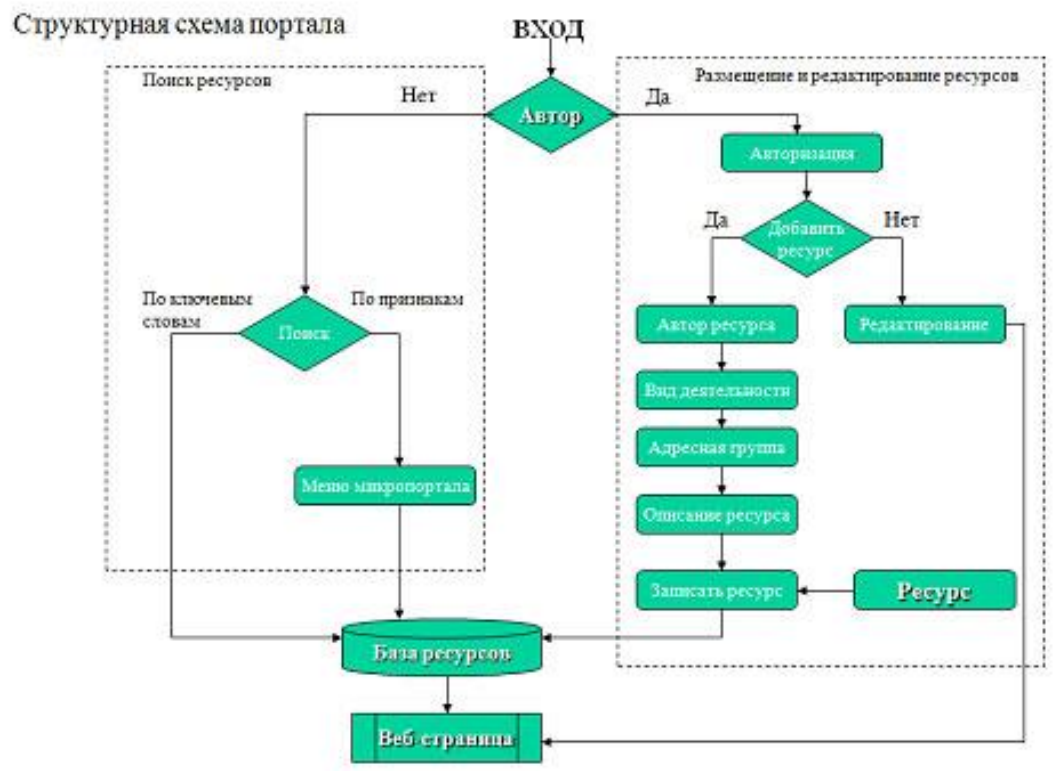

Рис.2. Структурная схема портала. 
Таблицы связей - таблицы, которые позволяют осуществлять сложную связь между справочниками и задавать сложные выборки из базы данных.

К справочникам относятся следующие таблицы: округов (заполняет администратор) - справочник с перечнем всех округов; регионов (заполняет администратор) - справочник с перечнем всех регионов; городов - справочник с перечнем городов в которых проживают авторы, находятся организации, размещены сайты и т.п.; организаций - справочник организаций; видов организаций (заполняет администратор) - справочник, который делит организации по видам (вузы, школы, НИИ и т.п.); видов деятельности (заполняет администратор) - справочник видов деятельности (научная, международная, т.п.); научного аппарата (заполняет администратор) - справочник наименований научных аппаратов, которым пользовался Автор в своем материале («реляционные базы данных» при описании проекта ИАС «Университет»); дисциплин (заполняет администратор) - справочник перечня дисциплин, к которым относится размещаемый ресурс.

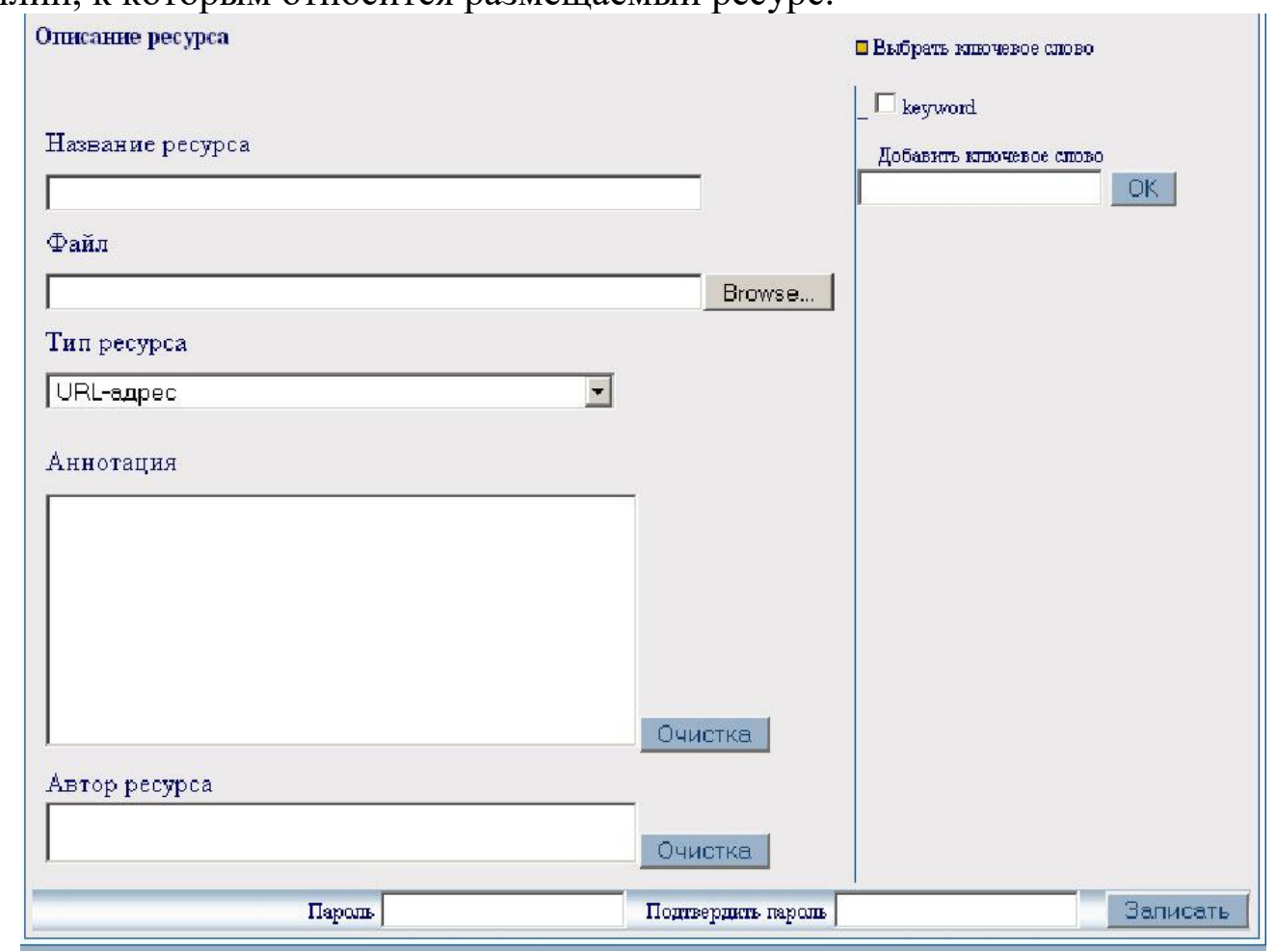

Рис.3. Описание ресурса.

Для различных организаций этот справочник имеет не только разное содержание, но и различную структуру. Для Вол ГУ это справочник состоит из нескольких справочников кафедра - специальность - группа предметов - предмет. Для других организаций, например, школ, он имеет структуру вид деятельности предмет; тип доступа (заполняет администратор) - справочник, определяющий виды доступа к ресурсу (открыт, закрыт, открыт на время и т.п.); ключевых слов справочник ключевых слов, которые вносит Автор в качестве слов для поиска и которые задет пользователь для поиска ресурса по ключевому слову; адресная группа (заполняет администратор) - справочник видов групп пользователей, которым предназначен ресурс (студент, школьник, учитель, преподаватель, др.); язык (заполняет администратор) - справочник списка языков, на котором выполнен ресурс (статья на немецком языке) или для которого он предназначен (стажировка по английскому языку); должность - справочник списка должностей «Авторов» ресурса; создатель (заполняет администратор) - справочник типов участников издания (автор, редактор, главный редактор, художник, корректор и т.п.); отдел - справочник отделов. 
Для различных организаций он разный. Для Вол ГУ это справочник факультетов и отделов Вол ГУ, для других организаций - линейный перечень отделов или структура, предоставленная организацией любого уровня вложенности.

К таблицам ресурсов относятся следующие таблицы: Автор - таблица с набором полей авторизованного автора; Ресурс - таблица с перечнем всех вносимых Авторами ресурсов; Тип ресурса - перечень всевозможных типов ресурсов. По этой таблице определяется таблица для ввода индивидуальных параметров ресурса.

Таких таблиц три - для ввода текстового ресурса, для ввода данных о персоналиях, для ввода информации о разделах: текстовый документ - таблица с параметрами для ввода текстового документа; персоналии - таблица для ввода данных о персоне; сайт - таблица для ввода данных о сайте.

В случае возникновения новых видов ресурсов, информация о которых не вписывается в данные три таблицы, создается новый Тип ресурса и для него создается новая таблица с перечнем полей, необходимых для описания данного peсурса. При этом схема работы со старыми данными не нарушается, т.к. она осуществляется через таблицу третьего вида - Таблицу связей.

К Таблице связей относится таблица - истории ресурса; таблица, которая осуществляет связь между таблицами: Автор; таблица ресурса; одна из таблиц данных (Текстовый документ, Персоналии, Сайт, др.); адресная группа.

История ресурса позволяет осуществлять связи с различными таблицами ресурсов, адресными группами, типами ресурсов и Авторами. При такой конфигурации таблиц базы данных один и тот же Автор может выступать как автор многих ресурсов и один и тот же ресурс может иметь многих авторов. Выборки возможны по любому из полей справочников или таблиц ресурсов.

Можно определить степень принадлежности к тому или иному направлению или, точнее, к соответствующему признаку элементов базы данных, а, следовательно, положение элемента базы данных в полученном результате поиска ресурса, что естественно, повышает эффективность поисковой системы.

Выводы.

Динамика развития портала обеспечивается принципом организации его структуры. Размещенный ресурс автора определяет путь к ресурсу по признакам базы данных, обозначаемым автором при его описании. Если из авторского микропортала удаляются все ресурсы, микроструктура с навигацией к ней перестает существовать, и пользователь не будет тратить время на поиск несуществующих ресурсов - это один из методов повышения эффективности поисковой системы.

Поиск целевой адресной группы осуществляется навигационной структурой портала, остальные пользователи могут использовать стандартный поиск по ключевым словам, который поддерживается описанием ресурса при его определении в базу данных автором.

Развитие структуры и навигации портала, а, следовательно, управление контентом осуществляется авторами ресурсов, что способствует эффективному функционированию информационной системе веб-портала.

$$
* * *
$$

1. Буханцева Н.В., А.А. Воронин Реализация деятельностного подхода при проектировании научнообразовательного портала Волгоградского государственного университета // Научно-методическая конференция «Современные информационные технологии в образовании: Южный федеральный округ, 2004. - С.52-54.

2. Воронин А.А., Мишин С.П. Модель оптимального управления структурными изменениями организационной системы // Автоматика и телемеханика. 2002. - №8. - С.136-150.

3. Гайдамакин Н.А. Автоматизированные информационные системы, базы и банки данных. М: Гелиос APB, 2002. $-368 \mathrm{c}$.

4. Рыбина Г.В. Основы построения интеллектуальных систем. - М: Изд. Дом «Инфа-М», 2010. С.18. 


\section{Гонова Н.В. ${ }^{1}$, Винник В.К. ${ }^{2}$ \\ Место и роль общеобразовательной организации в формировании человеческого капитала \\ ${ }^{1}$ МБОУ «Кадетская школа-интернат» \\ ${ }^{2}$ Нижегородский государственный университет им. Н.И. Лобачесвкого (Россия, Нижний Новгород)}

doi 10.18411/spc-04-02-2019-04

idsp sciencepublic-04-02-2019-04

Богатством нашей страны является человек. Развитие материальных, интеллектуальных и духовных возможностей человека, накопление человеческого капитала становится наиболее важной задачей государства и основным вложением инвестиций. Инвестиции в человеческий капитал - это инвестиции в долголетие и качество жизни. В возрасте до двадцати пяти лет, приоритетными вложениями для государства в человеческий капитал, должны стать инвестиции в качественное образование.

Сегодня, когда роль человеческого капитала возрастает многократно и происходят существенные перемены в разных отраслях и сферах деятельности, возникает новый тип общества называемый информационным или постиндустриальным. По мнению классика менеджмента П.Друкера, данное общество не будет ни капиталистическим, ни социалистическим. Это будет общество знаний, которые уже являются ключевым ресурсом, основой производительной силы. П.Друкер приходит к заключению, что в современную эпоху традиционные ресурсы, факторы производства (капитал, труд, земля) становятся второстепенными, а на первый план выходят знания [1].

В связи с переходом общества в постиндустриальный период, сегодня особое место занимают «знания» и процесс их получения соответственно. Государству, обществу необходим «новый человеческий капитал», по-новому мыслящий, оценивающий, работающий. Нужно новое поколение нравственно и духовно зрелых, самостоятельно активных и компетентных граждан, живущих и работающих в свободной демократической стране в условиях информационного общества и рыночной экономики.

Понятие «человеческий капитал» было рассмотрено в трудах Г. Беккера, У. Боуэна, Э. Дженисона, Т. Шульца и др. На сегодняшний день существуют множество подходов к определению данного понятия. Опираясь на исследования Г. Н. Тугускина, В. Д. Дорофеева [2,3] и др., мы определяем «человеческий капитал» - как совокупность знаний, умений, навыков, использующихся для удовлетворения многообразных потребностей человека и общества в целом. Отталкиваясь от этого, теперь сформулируем нынешнюю и дальнейшую позицию и роль образовательной организации в современном мире.

Безусловно общеобразовательные организации являются мостом, связывающим бесформенное начало каждого индивида и конечный результат - личность, которая способна приносить пользу обществу в разных ее сферах. Без этого связующего моста обойтись нельзя, к тому же он является единственно признанным государством аспектом в вопросе образования и формирования человеческого капитала. Человеческий капитал - главный актив экономики, оказывающий огромное воздействие на конкурентоспособность страны. Образование способствует повышению качества жизни людей и осуществлению ими своих гражданских прав и обязанностей. Образование делает жизнь человека богаче, развивая в нем познавательные и социальные навыки. Нам стоит научиться рассматривать внутреннее составляющее образовательного процесса как единое, скрытое целое, которое стремительно развивается естественно и пропорционально с другими составляющими жизни. Ведь 
развитие человеческого капитала - это развитие мобильной личности, как физически, так и интеллектуально. Все затраты на развитие рассматриваются как инвестиции в человеческий капитал.

Еще один нюанс связанный с образовательной организацией заключается в исполнении еще одной роли. Выше мы часто употребляли слово «знание». Что предполагается под этим словом сегодня? Сейчас само государство все еще задает тенденцию понимания знания как набор каких -то понятий. В этом-то и стоит проблема, что власть не дальновидна и полноценно не видит судьбу, отчасти одного человека при таких условиях. Так как страна является демократической, то она предполагает иметь человеческий капитал как нераздельную часть всего мира, при том, что происходит инициативный процесс глобализации, то есть - это реальный осязаемый мир, который говорит нам следующее определение «знания». Знание - это умение видеть в беспорядке - порядок и к тому же эффективно использовать это для решения любых задач, основываясь на таком источнике, дополняя его, создавая карту информации. Соответственно на это должны ориентироваться образовательные организации.

Таким образом, мы определили место и роль общеобразовательной организации в формировании человеческого капитала. Сегодня образовательные организации претерпевают реформаторские годы, что конечно является хорошим признаком.

$$
* * *
$$

1. Друкер П. Практика менеджмента. Перевод с англ.: М.: издательский дом «Вильямс», 2006. 400с.

2. Тугускина Г.Н. Особенности оценки человеческого капитала в стоимости предприятия// Экономика и управление собственностью, 2012, №3, с. 45-49

\section{Даминова Ш.К. \\ Самообразование - оптимальная форма повышения квалификации}

Институт переподготовки и повышения квалификаџии руководителей и специалистов работников народного образования имени А.Авлони

(Узбекистан, Ташкент)

doi 10.18411/spc-04-02-2019-05

idsp sciencepublic-04-02-2019-05

\section{Аннотация}

В образовательном учреждении, специализированного на самом распространённом методе повышения квалификации работников народного образования (институт, центр) в полной форме используются такие формы образования, как непосредственный, дистанционный, тогда как получение опыта в форме стажировки (в образовательных учреждениях, органов управления образования, за рубежом) в основном, применяются для повышения квалификации работников органов управления. Специфические особенности организации повышения квалификации на основе таких видов образования освещены в ряде исследований и статьях ученых, исследователей и специалистов.

Ключевые слова: переподготовка и повышение квалификации, формы образования, дистанционная образования, самообразование,

\section{Abstract}

In Specialized Educational Institutions the forms of upgrading professional skills through face to face, in distance that are over spread methods in the system of Professional Development of public educational institutions (institutes, centres) as well as in traineeship (in educational institutions, educational management departments, abroad) are mainly followed for professional development of public education personnel in managerial 
authorities. Specific features of organization professional development basing on such type of educational forms investigated a range of researches and articles of scholars, researchers and specialists in this field.

Keywords: In-Service and Retraining Professional skills, forms of education, Distance Education, Self study.

Современные реформы в нашей стране, проводимые в сфере образования, направлены на воспитание всесторонне развитого, продвинутого поколения, способного занять достойное место в жизни. Безусловно, поставленная перед нами задача зависит от потенциала педагогических кадров. Именно поэтому переподготовка и повышение квалификации мыслящих по-новому, инициативных руководящих кадров и педагогов, небезразличных к будущему родины, обеспечение образовательных учреждений системы народного образования высококвалифицированными педагогическими кадрами всегда были в центре внимания руководства страны.

В образовательном учреждении, специализированного на самом распространённом методе повышения квалификации работников народного образования (институт, центр) в полной форме используются такие формы образования, как непосредственный, дистанционный, тогда как получение опыта в форме стажировки (в образовательных учреждениях, органов управления образования, за рубежом) в основном применяются для повышения квалификации работников органов управления. Специфические особенности организации повышения квалификации на основе таких видов образования освещены в ряде исследований и статьях ученых, исследователей и специалистов. До сих пор остаются проблемными повышение квалификации с использованием обучения непосредственно в базовом образовательном учреждении повышения квалификации и получение знаний на основе самообразования.

Следовательно, реформы, проведённые в нашей стране, и опыт показал, что важным фактором является создание необходимых условий, достижение эффективных результатов с использованием оптимальных методов, уменьшая расходы для работников, независимо от сферы их деятельности. Особую важность имеют дальнейшее расширение охваченности повышением квалификации работников системы народного образования, улучшить эффективности повышения квалификации, направить на саморазвитие, максимально используемых на практике возможностей, повышение творческого потенциала работников народного образования благодаря их стимулированию-мотивации, форма самообразования повышения квалификации для создания здоровой конкурентоспособной среды в коллективе и в обществе.

Использование возможностей повышения квалификации на основе самообразования, считающегося эффективной и оптимальной формой непосредственного и косвенного повышения квалификации работников народного образования, считаются удобной формой для работающих в этой сфере руководителей, в особенности, педагогических работников.

В Постановлении Кабинета Министров Республики Узбекистан №25 “О дальнейшем усовершенствовании системы переподготовки повышения квалификации педагогических кадров" от 16 февраля 2006 года указано: Повышение квалификации на основе самообразование направлено на повышение профессионального мастерства, расширение профессиональных способностей, научного кругозора руководителей, педагогов и специалистов образования, предусматривает непрерывное самостоятельное усвоение новых знаний, навыков и квалификации по своей должности и специальности.

Приобретение знаний на основе самостоятельного образования является неотъемлемой частью непрерывного образования (повышения квалификации) кадров образовательных учреждений (руководителей и педагогов), стимулирующей изучение информационных технологий. Если самостоятельное образование осуществлено в установленном порядке по соответствующим учебным программам повышения 
квалификации, такому кадру на основе результатов итогового контроля знаний образовательным учреждением по повышению квалификации выдаётся типовой документ (сертификат) о повышении квалификации.

Такая форма повышения квалификации предполагает освоение материала благодаря самостоятельному обучению на основе отдельного плана, который составлен самим обучающимся и утверждённым образовательным учреждением повышения квалификации.

Установлено, что повышение квалификации в форме приобретения знаний на основе самообразования рекомендуется для слушателей со стабильным высоким профессиональным рейтингом, овладевшим практическими навыками по работе с современными информационными технологиями, способных критически и творчески подходить к процессу самосовершенствования. Следовательно, целесообразно внедрение данной формы повышения квалификации в качестве стимулирующего фактора для творческих педагогических сотрудников системы народного образования, непрерывно работающих над собой.

В текущих документах указан периодичность и продолжительность повышения квалификации для руководящих кадров образовательных учреждений и для специалистов работников народного образования - 1 раз в 3 года, а для педагогических кадров - 1 раз в 5 лет. Следовательно, исходя из вышеуказанных, сроки повышения квалификации руководящих или педагогических работников непосредственно связаны не только с их потребностями, но и формами повышения квалификации. В системе народного образования проводится множество научных изысканий и исследований по организации повышения квалификации педагогов. В этих исследованиях, в основном, проводилась работа, касающаяся обучения в специализированных образовательных учреждениях (институт, центр) по формам образования непосредственного и дистанционного обучения. Но самообразование (самостоятельное обучение) не учтено как самый оптимальный вид повышения квалификации с материальной и экономической точки зрений, способствуюший повышению сочиальной активности, направленный на определение личной потребности и способный $\kappa$ использованию в качестве стимулирующего фактора. Основная цель повышения квалификации направлена на удовлетворение профессиональной потребности педагогов, на основе этого повышение качества и эффективности в образовательных учреждениях, создание максимальных возможностей для получения учащимися полноценных знаний, основанных на результативности.

Самообразовательная деятельность, умение ее осуществлять - важное качество любого профессионала, особенно в годы усиленного развития новейших технологий и компьютерной техники, которые затрагивают все сферы жизни в период становления информационного общества. Само свойство информации предполагает ее постоянное обновление, а людей вынуждает не отстать в понимании и применении этой информации в своей профессиональной деятельности и требует от человека умения самостоятельно усваивать новые знания и навыки.

Всякая образовательная система, помещаемая в образовательной пространство, создается для реализации деятельности участников образования. Зачастую человек обращается к самообразованию в силу неких внутренних побудительных мотивов, связанных как с саморазвитием человека, так и с его потребностью познать себя, свою духовную сущность и самореализовываться и как личность, и как специалист-профессионал.

Прохождение полного курса повышения квалификации в традиционной форме профессионалу своего дела, непрерывно работающего над собой, приводит к определенным несоответствиям.

С помощью выше приведенных факторов руководители образовательных учреждения и педагоги могут относительно определить свою профессиональную потребность. Этим создаются удобства для составления Заказчиком, направляющим 
работников на курсы повышения квалификации, плана повышения квалификации, основанного на потребностях.

Наряду с этим в целях стимулирования высокой профессиональной компетенции слушателя, принятого на курсы повышения квалификации, открываются широкие пути для предоставления соответствующих рекомендаций аттестационной комиссии о преждевременном повышении квалификационной категории педагога в установленном образовательном учреждении, популяризации методических рекомендаций, небольших исследований по актуальным проблемам управления и образования.

Благодаря внедрению повышения квалификации в форме приобретения знаний на основе самостоятельного обучения гарантируется экономия государственного бюджета, повышение профессиональной компетентности руководителей и педагогических работников системы народного образования, развития здоровой конкурентоспособной среды благодаря стимулированию работников отрасли, непрерывному повышению квалификации, ведущих специалистов.

$$
\text { *** }
$$

1. Национальная программа по подготовке кадров. - Национальная база данных законодательства, 05.01.2018 г., № 03/18/456/0512

2. Постановление Кабинета Министров Республики Узбекистан “О дальнейшем усовершенствовании системы переподготовки повышения квалификации педагогических кадров”, 16.02.2006 г., Собрание законодательства Республики Узбекистан, 2006 г., № 6-7, ст. 39; 2011 г., № 25, ст. 260; 2012 г., № 33-34, ст. 390

3. Айзенберг А. Я. Самообразование: история, теория и современные проблемы: учеб. пособие для вузов. М.: Высш. шк., 1986.

4. Ганченко И.О., Развитие личности педагога в системе непрерывного профессионального самообразования: Автореф... дисс. докт. пед. наук. -Ставрополь, 2004.

5. Тургунов С.Т., Теоретические основы управленческой деятельности директоров общеобразовательных учреждений: дисс. док. пед. наук. -Ташкент, 2007.

\section{Дрёмина С.Л., Демченко С.Г.}

Создание базовой переводческой компетенции студентов-не филологов

Дальневосточный государственный аграрный университет (Россия, Благовещенск)

doi 10.18411/spc-04-02-2019-06

idsp sciencepublic-04-02-2019-06

Современные межкультурные интернациональные связи обусловили жизненную необходимость владения иностранным языком выпускниками неязыковых вузов. Знание иностранного языка - обязательное условие участия России в Болонском процессе. Главным направлением стратегии государственной политики в образовании стран Европейского союза, России является компетентностный подход.

Переводческая компетенция означает готовность к применению знаний в конкретных условиях перевода. В методической литературе переводческая компетенция определяется как совокупность языковых и других профессиональных знаний, умений и навыков, позволяющих переводчику эквивалентно и адекватно передавать содержание исходного текста средствами языка перевода с учетом межъязыковых и межкультурных различий. Она включает в себя базовые, специфические и специальные составляющие.

К базовым составляющим переводческой компетенции относятся знания, умения и навыки, в той или иной мере необходимые переводчику во всех видах перевода и независимо от жанра переводимого текста.

Специфические составляющие - это знания, умения и навыки, необходимые в каком-либо одном виде перевода. Специальные составляющие - это знания, умения и навыки, необходимые при переводе текстов определенного стиля и жанра. 
Следуя принципу преемственности, в вузе следует продолжать развивать иноязычную коммуникативную компетенцию и одновременно с первых занятий представляется целесообразным приступить к формированию переводческой компетенции, центральное место в которой занимают умения, возникшие в результате синтеза знаний и практических навыков.

Формирование базовой составляющей переводческой компетенции вооружает студента способностью выполнять перевод в существенной мере осознанно и с позиций понимания сложной природы перевода, его технологии, совершенствоваться в течение всей своей профессиональной жизни. Вслед за Л.К. Латышевым, полагаем, что, формируя базовую составляющую, преподаватель апеллирует, главным образом, к разуму обучаемых и их языковому чутью. При переводе текстов по специальности подключается интуиция. Студенты, еще не обучавшиеся переводу, переводят интуитивно. Эту интуитивную компоненту переводческой компетенции рекомендуется культивировать, как и разумную, ибо в переводе «работают» и та и другая. Они взаимодействуют: основную нагрузку несет интуитивная компонента, компонента сознания делает перевод более технологичным, она же эффективно работает при столкновении с «нестандартными» переводческими трудностями.

В основе переводческой компетенции лежат знания двух языков и двух культур, готовность создавать и понимать тексты на двух языках и переходить от одного языка к другому. Обучая переводу, необходимо научить пользоваться словарями, анализировать параллельные тексты, применять переводческие трансформации, уметь объяснить свои действия и совершенствовать навыки перевода.

На первом этапе обучения в неязыковом вузе (1 и 2 семестры) работа со словом и отдельными грамматическими структурами представляется нам наиболее доступной и эффективной. Цель формирования переводческой компетенции в этот период заключается в формировании ценностного отношения к слову, его мотивированного употребления в конкретной ситуации. Студентам предлагается выполнить следующие задания:

a) выписать и подобрать эквиваленты на изучаемом языке к словам, которые очень часто встречаются в газетах и на телевидении;

б) в тексте (10-15 предложений) на родном языке заменить все слова синонимами, антонимами, описаниями, не нарушая при этом нормы родного языка и сохраняя максимальную близость к оригиналу по содержанию;

в) составить из 5-6 случайно подобранных слов предложения со всеми значениями;

г) не меняя грамматической структуры простого предложения (5-7 слов), составить другое предложение.

На втором этапе обучения в неязыковом вузе (3 и 4 семестры) мы переходим к переводу текстов. Цель заданий - добиться того, чтобы студенты вышли на такой уровень переводческой компетенции, который позволил бы им практически решать конкретные проблемы.

Все задания можно разделить на задания, предшествующие переводу, задания, выполняемые при переводе, и задания, выполняемые после перевода. Такая система заданий очень близка к тому, что делает переводчик в реальной жизни: переводческий анализ, сам процесс перевода и редактирование.

Задания (общее знакомство с текстом), предшествующие переводу, включают в себя умение понимать прагматическую установку и адресность текста с целью их точной передачи на языке перевода, умение воспринимать как смысловую, так и языковую информацию текста с целью ее передачи на языке перевода (попутно рассматриваются лексические и грамматические трудности, с которыми сталкиваются студенты). 
Задания (общее знакомство с текстом), выполняемые при переводе, включают в себя умение анализировать текст оригинала, выбирая переводческие решения, умение оформлять научный текст на языке перевода в соответствии с требованиями языка перевода (полный или частичный перевод текста с использованием справочной литературы или без нее).

Задания, выполняемые после перевода, предполагают чтение переводов, обсуждение и выбор наиболее удачного перевода или составление из наиболее удачных предложений нового текста перевода, а также корректирование переводов.

Роль преподавателя при обучении переводу специальных текстов состоит в том, чтобы привить вдумчивый подход к пониманию перевода, постоянно проводить языковые параллели, показывать специфику другой языковой системы. Для того, чтобы уметь переводить, обучающийся должен:

1) владеть необходимым объемом знаний в области теории перевода (эквивалент и аналог, переводческие трансформации);

2) иметь навыки компенсации потерь при переводе; контекстуальных замен; различать многозначность слов, значения интернациональных слов в родном и иностранном языке и т.д.;

3) уметь адекватно передавать смысл общенаучного, технического текста с соблюдением норм родного языка;

4) уметь пользоваться источниками информации - общими и специальными (разного рода словарями и справочной литературой)

5) владеть терминологическим минимумом, специальными оборотами речи и несвободными словосочетаниями;

6) знать грамматические особенности научно-технической литературы и этапы с переводным текстом;

7) знать особенности каждого жанра научно-технической литературы.

Конечно, невозможно выработать у обучающихся техническим специальностям всех умений и навыков переводчика-профессионала, но обучить основам переводческой техники возможно и нужно. Ибо только высококвалифицированный технический специалист, хорошо знающий предметную область и ее специфическую терминологию и в достаточной мере владеющий иностранным языком, сумеет грамотно изложить свои мысли на языке перевода.

$$
* * *
$$

1. Латышев, Л.К. Структура и содержание подготовки переводчиков в языковом вузе/ Л.К. Латышев, В.И. Провоторов. - М., 2001.

2. Чеботарев, П.Г. Перевод как средство и предмет обучения/ П.Г. Чеботарев. -М.: Высшая школа, 2006.

\section{Каргиева О.Н. \\ Практико-ориентированная образовательная деятельность в подготовке будущих учителей начальных классов}

Государственное бюджетное образовательное учреждение высшего образования «Северо-Осетинский государственный педагогический институт»

doi 10.18411/spc-04-02-2019-07

(Россия, Владикавказ)

idsp sciencepublic-04-02-2019-07

Масштабные изменения, происходящие в современном российском обществе, всестороннее обновление образовательной системы страны, существенный пересмотр принципов функционирования системы образования, предъявляют высокие требования к профессиональной подготовке учителя. 
В современном обществе цель педагогического образования заключается в подготовке компетентных, конкурентоспособных специалистов, востребованных системой образования, готовых к быстрой адаптации в условиях непрерывного обновления принципов формирования и организации содержания образования на всех его уровнях, к перепрофилированию в педагогической деятельности, к самостоятельному принятию решений и эффективной образовательной деятельности на уровне мировых стандартов.

При прогрессировании тенденции перехода к компетентностному подходу в развитии педагогического образования целью педагогического образования также является становление профессиональной компетентности как интегральной характеристики, определяющей «способность решать профессиональные проблемы и типичные профессиональные задачи, возникающие в реальных ситуациях профессиональной педагогической деятельности, с использованием знаний, профессионального и жизненного опыта, ценностей и наклонностей» [2].

Исходя из сущностных характеристик компетентностного подхода, обновление профессионального образования невозможно без усиления практикоориентированности педагогического образования при сохранении его фундаментальности, что в свою очередь, обеспечивает эффективную профессиональную подготовку выпускника педагогического вуза, способного к решению разных по уровню сложности задач в будущей профессиональной деятельности.

Практико-ориентированная образовательная деятельность представляет собой систему организационно-педагогических условий, обеспечивающих формирование профессиональных компетенций в процессе прохождения учебной практики. В условиях практико-ориентированной образовательной деятельности решаются конкретные практические задачи по актуализации профессиональной компетентности [1].

Практико-ориентированная образовательная деятельность позволяет:

— выявить уровень сформированности профессиональных компетенций студента;

- сформировать у студентов практические способности в ходе образовательного процесса;

- с учетом реальных учебных возможностей студентов создавать реальные профессиональные ситуации, решать производственные и другие задачи;

- приобрести необходимый минимум профессиональных умений и навыков, профессиональную мобильность и компетентность, что и должно соответствовать образовательному стандарту нового поколения [4].

Одним из условий подготовки компетентного практико-ориентированного специалиста, является взаимодействие ученых, методистов и практиков по формированию профессиональных компетенций будущих педагогов.

В рамках работы по взаимодействию с работодателями Северо-Осетинский государственный педагогический институт (СОГПИ) организовал деятельность инновационной модели «вуз - базовая кафедра», как интегрированную образовательную структуру на базе организаций, осуществляющих образовательную, научную, производственную деятельность по профилям образовательных программ Института.

Цель создания кафедры - повышение эффективности и качества практической подготовки студентов, путем реализации Институтом части образовательной программы соответствующего направления подготовки, направленной на формирование, закрепление и развитие профессиональных умений и компетенций обучаемых, на базе Института, путем интеграции деятельности, в том числе на основе 
привлечения к преподаванию высококвалифицированных специалистов-практиков, образовательного и научного потенциала организации [3].

Кафедра организует осуществление деятельности по повышению профессионального потенциала Института и организации, в том числе, через: привлечение специалистов организации к преподавательской деятельности; поддержку и развитие научно-педагогических школ Института; проведение совместных научнометодических мероприятий (семинаров, конференций, круглых столов) по значимым направлениям деятельности Института; проведение стажировок.

На основании анализа базовыми кафедрами результатов прохождения студентами педагогической практики в учебный процесс СОГПИ включены активные методы обучения и конкурсные задания. При выполнении зачетных работ студентам предлагается написать эссе, разработать фрагмент урока и соответствующие ему цель и задачи, разработать структуру и ход внеурочного занятия. Обучающиеся решают ситуативные педагогические задачи, анализируют нестандартные ситуации, предлагают свои пути решения проблемы, обосновывая их с теоретической точки зрения.

В рамках проведения зачетного занятия по дисциплине «Педагогика» студентам предлагается подготовить интерактив с родителями, направленный на решение ситуативной педагогической задачи.

В ходе изучения учебной дисциплины «Педагогика межнационального общения в поликультурном образовательном пространстве»») подготавливается этнографический атлас с презентацией «Этнографическая экспедиция». При выполнении заданий студенты отрабатывают и демонстрируют умения творчески и содержательно представить материал конкретного направления с использованием информационнокоммуникационных технологий.

Одной из эффективных практико-ориентированных и увлекательных форм самореализации и самосовершенствования студентов являются олимпиады, фестивали, конкурсы профессионального мастерства. Наблюдения и опыт показывают, что участники таких соревнований получают информацию, которую они в обычных условиях усваивают за недели и даже месяцы, а иногда и вовсе не могут ее получить в традиционной образовательной системе.

Начиная со 2 курса, ежегодно, в рамках «Недели педагогики», в СевероОсетинском государственном педагогическом институте проходит «Педагогическая олимпиада», организованная кафедрой педагогики.

Данное соревнование дает студентам возможность совершенствовать навыки самостоятельного эффективного решения задач профессиональной деятельности, проявить себя в деятельности, максимально приближенной к реальной, а педагогам просмотреть, оценить, если не всех, то максимально возможное количество обучающихся средних курсов (2-3 год обучения).

Во время проведения олимпиады конкурсанты выполняют задания практической направленности, с целью выявления сильнейшего. Конкурсантам выдается не только само задание, но и критерии выполнения работ. Оценивают работы преподаватели и представители работодателей. Все недочеты фиксируются для дальнейшего разбора на практических занятиях по дисциплинам педагогического цикла.

Представленный системный подход приносит результат. Это и мотивация интереса к изучаемым дисциплинам, и сложившиеся взаимоотношения внутри группы при подготовке, взаимопомощь. Важно, чтобы эта традиция сохранилась, и обучающиеся старших курсов передавали свои знания и опыт студентам младших курсов.

Подобные конкурсы помогают успешно решать задачи повышения качества подготовки специалистов, позволяют создать благоприятную среду для развития интеллекта, совершенствования профессиональных умений и навыков, развития 
профессионального и креативного мышления студентов, способствуют формированию опыта творческой деятельности в профессиональной сфере. Кроме того, для конкурсов характерно соревновательное творчество участников, помощь в развитии творческого мастерства каждого участвующего студента.

Таким образом, внедрение практико-ориентированных технологий в образовательный процесс педагогического вуза, является эффективным инструментом для формирования профессиональных компетенций, повышения престижа и популяризации профессии педагога и организации профессиональной подготовки кадров, соответствующих современным международным стандартам по уровню квалификации, качеству труда и владению передовыми профессиональными технологиями.

$$
* * *
$$

1. Бахметова Ю.Н. Практико-ориентированная образовательная деятельность студентов психологопедагогических специальностей // Вестник Краснодарского государственного института культуры. 2016. - №4(8) [Электронный ресурс]. URL: vestnikkguki.esrae.ru/16-296 (дата обращения: 30.01.2019).

2. Игна О.Н. Ведущие цели и принципы современной профессиональной подготовки учителя // Вестник ТГПУ (ТSPU Bulletin). - 2015. - №12 (165). С. 36 - 41.

3. Положение о базовой кафедре СОГПИ [Электронный ресурс]. URL: http://sogpi.org/ru (дата обращения: 29.01.2019).

4. Ялалов Ф. Г. Деятельностно-компетентностный подход к практико-ориентированному образованию // Интернет-журнал "Эйдос". - 2007. [Электронный pecypc]. URL: http://www.eidos.ru/journal/2007/0115-2.htm. (дата обращения: 25.01.2019).

\section{Лукьянова Д.Е., Назранова К.А. \\ Взгляды Е.Н. Медынского на проблему внешкольного образования в России}

Лесосибирский педагогический институт - филиал ФГАОУ ВО «Сибирский федеральный университет» (Россия, Лесосибирск)

doi 10.18411/spc-04-02-2019-08

idsp sciencepublic-04-02-2019-08

Проблема дополнительного образования детей на данный момент является неоспоримой, ведь она связана с новым пониманием самой сущности образования детей. Дополнительное образование детей на современном этапе социально востребовано, ведь обладает достаточной мобильностью, интерактивностью, способностью быстро и точно реагировать на современный мир в интересах ребенка, его семьи, общества и государства. Оно предполагает привлечь к себе особое внимание и поддержку со стороны общества и государства. Изучение проблемы дополнительного (внешкольного) образования на современном этапе развития остается одной из самых востребованных. Еще дореволюционными историками школы и педагогики А.У. Зеленко, П.Ф. Лесгафтом, К.А. Фортунатовым, С.Т. Шацким, М.И. Демковым, Е.А. Звягинцевым, С.А. Золотаревым, П.Ф. Каптеревым, Н.В. Чеховым, В.И Чарнолуским, Е.Н Медынским и др. был осуществлен теоретический анализ этапов, принципов организации внешкольного образования. Некоторые педагоги пытались дать определение понятию «внешкольное образование», ведь изучение данного социальнопедагогического феномена было затруднено из-за отсутствия общетеоретических подходов к определению понятий.

Одним из первых определение термину «внешкольное образование» дал Е.Н Медынский. Он писал, что понятию «внешкольное образование» как нельзя лучше соответствует понятие «развитие», которое звучит как постоянная внутренняя работа личности над всеми элементами человеческого «я». Не только психическими, но и физическими. Внешкольное образование подразумевает не только развитие умственное, но развитие гармоническое [2, с.23]. Однако педагогом дается еще одно 
определение внешкольного образования, которое сам Евгений Николаевич называет полным: «Внешкольное образование - это всестороннее гармоническое развитие личности или человеческого коллектива в умственном, нравственно-социальном, эстетическом и физическом отношениях» [2, с.25].

В своей работе «Энциклопедия внешкольного образования» Евгений Николаевич очень четко определяет задачи внешкольного образования-воспитания в России: 1. Ликвидация безграмотности; 2. Развитие социалистического мировоззрения; 3. Проведение в трудящиеся массы искусства [1, с.30].

Все формы внешкольного образования ученый разделил на три рода (вида): 1. внешкольные учреждения; 2. внешкольные мероприятия; 3. внешкольные организации.

И хотя мелкие просветительские общества и кружки стали возникать в сельских местностях уже после первой русской революции, в России роль государства в дореволюционный период в области внешкольного воспитания и образования характеризуется целым рядом запретительных мероприятий и полным отсутствием положительной деятельности, писал Е.Н Медынский. К просветительским обществам кружкам относились библиотечные общества и общества народных домов. Но развитие их шло очень медленно: с одной стороны, среди самого населения были очень слабы еще ростки самодеятельности, с другой - правительство царского режима всеми силами тормозила их возникновения [1, с. 76]. После революции 1917 года начался усиленный рост сельских просветительских обществ и кружков. Концу 1917 года по самому скромному подсчету, организовалась в России до 3000 просветительских обществ и кружков. В 1918 году рост их усилился еще более: редкое вольность не иметь теперь одного или нескольких таких обществ или кружков. По данным обследования 100 таких обществ в Нижегородской губернии на одно общество в среднем приходилось около 60 членов (Данные на 1918 г.) [2, с. 76].

Е.Н. Медынским были определены основные принципы внешкольного образования. По своему характеру они могут быть разделены на три большие группы: общие принципы внешкольного образования, принципы построения систем внешкольного образования и принципы организации образовательного процесса.

Никогда и нигде внешкольное образование не пользовалась таким вниманием государства как в России после Октябрьской революции. Колоссальные трудности и важности задачи встали перед Советской властью в деле внешкольного образованиявоспитания: 1) нужно было создать руководящие этим делом аппарат, отсутствующие у государства ранее;2) как земства в начале своей деятельности встретилась с полным отсутствием учителей, так, выдвинув в своей деятельности внешкольное образование На первый план, Советское правительство встала перед фактом отсутствия подготовленных вне школьников; 3) в соответствии с общеполитическими и социальными задачами революции приходилось вырабатывать соответствующие времени задачи внешкольного воспитания- образования.

Только сведениям всеобщего внешкольного образования наша просветительская работа станет планомерный, потеряет тот случайный характер, который, несмотря на всё развитие свое, она носила до сих пор: в одном мы ездили несколько сот народный библиотек, в другом едва насчитывается 23 десятка, в одной губернии сотни школ для взрослых, в другой 10-15, писал Е.Н. Медынский.

Таким образом можно сделать вывод, что деятельность Е.Н. Медынского в области внешкольного образования оставила большой след. Именно им были выделены формы и средства содействия внешкольному образованию, некоторые из которых актуальны и в настоящее время.

$$
* * *
$$

1. Медынский Е.Н Внешкольное образование. Его значение, организация и техника. — 2-е изд., знач. доп. и перераб. - М.: Книгоиздательство «Наука», 1916. - 327 с. (затем: М., 1918);

2. Медынский Е.Н Энциклопедия внешкольного образования, т. 1. - М., 1923 г. — 137 с. 


\section{Матвеева Е.C. \\ Внешняя среда образовательной организации как объект управления \\ Ульяновский государственный педагогический университет им. И.Н. Ульянова (Россия, Ульяновск)}

doi 10.18411/spc-04-02-2019-09

idsp sciencepublic-04-02-2019-09

Управление образовательной организацией невозможно без контроля внешних переменных, влияющих на неё. Многие процессы в организациях дошкольного образования, основного общего образования, профессионального образования зависят от внешних сил и явлений, действующих в глобальном внешнем окружении. В данной статье сделана попытка описать наиболее значимые факторы внешней среды, влияющие на образовательные организации.

Результативность организации зависит от точного представления факторов развития, а также целей, структуры и алгоритма функционирования механизма её управления. Для большинства образовательных организаций внешняя среда является конкурентной, поэтому анализ её переменных необходим для поддержания достаточной конкурентоспособности организации.

Внешняя среда обеспечивает организацию входящими ресурсами. Благодаря обратной связи на выходе организация получает информацию для оценки результатов и последующего выбора входящих ресурсов. Внешняя среда дает образовательной организации партнеров для решения текущих и перспективных задач. Именно во внешней среде находятся ресурсы и возможности для дальнейшего развития образовательного учреждения.

Для отечественных рынков образования характерно, что внешняя среда организаций подвижна, изменчива, и эти изменения определяют направленность деятельности образовательной организации, порождают возможности, ограничения или угрозы. Факторы внешней среды могут оказывать как положительное, так и отрицательное воздействие, следовательно, управленцам образовательных организаций необходимо направлять действия на то, чтобы получить максимальную выгоду из представленной возможности через постоянный анализ и сопоставление между собой фактов и явлений.

Факторы, внешней среды, оказывающие влияние на деятельность образовательной организации, подразделяют на две группы:

а) факторы прямого воздействия (поставщики трудовых ресурсов, конкуренты, государственные органы);

б) факторы косвенного воздействия (общественно-политические, научнотехнические, социокультурные, природно-экологические, социально-бытовые, производственно-экономические, духовно-нравственные, культурные).

Первую группу внешних факторов образовательная организация не только контролирует, но и способна строить с ними продуктивное взаимодействие. Факторы косвенного влияния, составляющие макросрежу организации, контролю не поддаются, но оказывают значительное влияние на систему образования.

На работу образовательной организации в настоящее время особенно влияют такие экономические факторы как рост финансирования образовательных организаций на государственном, республиканском, областном, муниципальном уровнях оказывает положительное влияние на развитие как системы образования в целом, так и отдельных образовательных учреждений. Демографические факторы также влияют на большинство рынков образовательных услуг. Среди ведущих социокультурных факторов сегодня можно назвать пропаганду здорового образа жизни и культурного наследия Российской Федерации. С ними связаны такие традиционные задачи воспитания как ценностей, традиций, установок, развитие коммуникативных способностей учащихся. 
Помимо данных традиционно выделяемых специалистами факторов $[1,2,4]$, на наш взгляд, для образовательной организации в настоящее время важны такие внешние факторы, как снабженческий, производственный и профессиональный.

Снабженческий фактор представляет собой влияние на образовательную организацию поставок оборудования, учебных пособий, тепло- и энергоресурсов. Без достаточного оснащения организация не способна осуществлять учебную деятельность на должном уровне качества. Качественные пособия и оборудование, эргономичная и экологически безопасная продукция, получаемая образовательной организацией, обеспечивает её конкурентные позиции на рынке.

Производственный фактор характерен для рынков услуг среднего профессионального образования (СПО) и высшего образования. Предприятия принимают решения по целевому направлению на обучение своих работников или их детей, осуществляя кадровую политику, вкладывая финансовые средства в развитие системы образования.

Профессиональный фактор, влияющий на образовательные организации, обусловлен уровнем развития той или иной отрасли производства, которые оказывают влияние на структуру системы образования: вузы и организации СПО ориентируются на наиболее востребованные профили профессиональной подготовки. Исходя из этого, строят свою работу и организации основного общего и дополнительного образования. Так, с развитием в 90-е годы в нашей стране рыночных отношений стали востребованы профессии, связанные с экономикой и юридической сферой, что отразилось и на содержании образовательных программ вузов, и на внимании к общественным наукам в школе. Для сегодняшнего дня характерен общественный запрос на профессионалов технической сферы, по этой причине не только СПО и вузы корректируют профили профессиональной подготовки, но и для школ и организаций дополнительного образования стали актуальны дисциплины физико-математического блока. То есть, внешняя среда несёт определенные ожидания, предъявляемые образованию, формирует и предъявляет социальный заказ на образование

На образовательное учреждение, в первую очередь, влияет его социальное окружение. Принято выделять следующие группы социального окружения (контактные аудитории) образовательного учреждения [3, с.155-162]: клиенты, заказчики, потребители, пользователи, поставщики ресурсов (в том числе - инвесторы, спонсоры, меценаты), партнёры, конкуренты, СМИ и другие институты, создающие общественное мнение об образовательном учреждении. Для работы с данными группами важно учитывать долгосрочные перспективы развития образовательного учреждения. Для эффективного управления образовательной организацией руководители должны уметь вступать в диалог с потребителями образовательных услуг обращаться к поддержке местной власти, работать с общественным мнением.

Таким образом, современной образовательной организации значимо внимательно изучать факторы внешней среды, социальный заказ. Соотнесение ресурсных возможностей образовательной организации с потенциальными рисками и возможностями её окружения необходимо для успешного функционирования.

$$
\text { **** }
$$

1. Ганаева, Е. А. Разработка маркетинговой стратегии образовательной организации. - М.: Флинта, 2015. - 112 c. URL : https://biblioclub.ru/index.php?page=book_view_red\&book_id=271818 (дата обращения: 21.01.2019).

2. Захарова, И. В. Образовательный маркетинг: учебно-методическое пособие. - Ульяновск: УлГПУ, 2017. - 37 c.

3. Корзникова, Г. Г. Менеджмент в образовании / Г. Г. Корзникова. - 2-е изд., перераб. и доп. $352 \mathrm{c}$.

4. Панкрухин, А. П. Новый контекст для маркетинга образовательных услуг: маркетинги интеллектуального капитала. URL: http://www.koism.rags.ru/publ/articles/19.php (дата обращения: 21.01.2019). 


\section{Михайлов Н.Г., Кавокин А.И. \\ Оптимизация двигательной активности детей 5 - 7 лет в дошкольной образовательной организации}

Московский городской педагогический университет

(Россия, Москва)

doi 10.18411/spc-04-02-2019-10

idsp sciencepublic-04-02-2019-10

\section{Аннотация}

В стать рассматриваются вопросы оптимизации двигательной активности детей дошкольного возраста. Полученная авторами информация об объёмах двигательной активности использованы для построения математической модели этого показателя с учётом уровня развития основных физических качеств у детей 5-7 лет. Ошибка при расчётах должных объёмов двигательной активности не превысила двух процентов от абсолютной величины, что позволяет рекомендовать разработанные модели для управления процессом физического воспитания.

Ключевые слова: двигательная активность дошкольников, математическая модель, физические качества, должный объём двигательной активности

\section{Abstract}

In becoming discusses optimizing locomotor activity of preschool children. The authors received information about volumes of motor activity used to construct mathematical models of this indicator taking into account the level of development of basic physical qualities of children 5-7 years. Error in the calculations of proper amounts of locomotor activity did not exceed two per cent of the absolute value that allows you to recommend models developed for the management of physical education.

Keywords: physical activity preschoolers, mathematical model, physical qualities, the proper amount of motion activity

В настоящее время специалисты в области системы образования указывают на необходимость решения проблемы оздоровления подрастающего поколения [3, 9]. В литературе отмечается, что одним их факторов, положительно влияющих на состояние здоровья детей дошкольного возраста, является определённая организация двигательной активности $[5 ; 7,8]$.

Двигательная активность имеет большое значение для развития детей дошкольного возраста, когда организм ребёнка активно формируется и претерпевает серьёзные морфологические перестройки под воздействием физических упражнений [1, $2,4,10]$.

Одним из путей решения этой задачи, является реализация комплексного подхода к организации физического воспитания дошкольников с помощью новых моделей построения физкультурно-оздоровительной деятельности дошкольников в образовательной организации дошкольников $[3,4,6$,$] .$

Цель исследования - построение математических моделей объёма двигательной активности у детей 5-7 лет.

Метод и организация исследования. Организованные движения включают физические упражнения, выполняемые на занятиях физической культуры в образовательных учреждениях и при занятиях в спортивных кружках, секциях, а неорганизованные движения подразумевают участие детей в играх, прогулках и во время самообслуживания.

Во время проведения сравнительного педагогического эксперимента производились измерения показателей физического развития, а также результаты в контрольных упражнениях, которые позволяют собрать достаточно точную 
информацию о состоянии и уровне зрелости психомоторики и уровне развития отдельных физических качеств у 182 дошкольников, включая 94 мальчиков и 88 девочек в возрасте 5-7 лет.

В ходе педагогического эксперимента проверялась возможность увеличения объёма двигательной активности дошкольников при помощи технологии, включающей традиционные и инновационные технологии физического воспитания. К числу первых относились технологии применения игровых методов, к числу вторых - технологии использования упражнений волновой биомеханики и упражнений ушу.

В основу моделей был положен регрессионный анализ, позволяющий рассчитать уравнения множественной регрессии, в которых объём выступает в качестве расчётного показателя, а в качестве информативных показателей - показатели в контрольных упражнениях. Математическая модель была построена по формуле:

$\mathrm{Y}=\mathrm{F}(\mathrm{X} 1, \mathrm{X} 2, \ldots, \mathrm{Xm})$,

где $\mathrm{Y}$ - зависимая переменная (результативный признак);

$\mathrm{X} 1, \mathrm{X} 2, \ldots \mathrm{Xm}$ - независимые переменные;

$\mathrm{m}$ - число независимых переменных.

Степень влияния факторов устанавливалась при помощи корреляционного анализа, между объёмом двигательной активности детей и результатами измерений показателей физической подготовленности дошкольников.

\section{Результаты исследования.}

Основное воздействие экспериментальной педагогической технологии было направленно на оптимизацию объемов двигательной активности у детей дошкольного возраста за время пребывания, в дошкольном образовательном учреждении. Результаты измерения объёма двигательной активности, в контрольных и экспериментальных группах у девочек и мальчиков, при завершении педагогического эксперимента представлены в таблице 1.

Анализ объёмов двигательной активности позволяет заключить, что применение экспериментальной технологии, включающей традиционные и инновационные технологии физического воспитания, позволяет увеличивать этот показатель у детей 57 лет, как у мальчиков, так и у девочек. Вместе с тем, показатели объёма двигательной активности у девочек имеют несколько меньшую величину по сравнению с величиной этого показателя у мальчиков. В ходе педагогических наблюдений этот факт получил объяснение. Девочки предпочитают игры с куклами при минимальном числе движений, включая такие операции как одевание кукол, укладывание их в постель, имитацию кормления за столом. Ребята же предпочитают игры с активным движением, включая передвижение по игровой комнате с машинками, игру с мячами и т.п.

Таблий 1.

Показатели объемов двигательной активности у мальчиков КГи ЭГ при проведении педагогического эксперимента

\begin{tabular}{|c|c|c|c|c|}
\hline \multirow{2}{*}{ Группа } & КГ & ЭГ & \multirow{2}{*}{$\begin{array}{l}\text { t- критерий } \\
\text { Стьюдента }\end{array}$} & \multirow{2}{*}{$\begin{array}{c}\text { Уровень } \\
\text { значимости, }\end{array}$} \\
\hline & \multicolumn{2}{|c|}{ мальчики } & & \\
\hline Средняя & $8875 \pm 158$ & $9612 \pm 217$ & 2,74 & $<0,05$ \\
\hline Старшая & $9814 \pm 155$ & $10458 \pm 211$ & 2,46 & $<0,05$ \\
\hline \multirow[t]{2}{*}{ Подготовительная } & $13563 \pm 175$ & $14323 \pm 265$ & 2,39 & $<0,05$ \\
\hline & \multicolumn{2}{|c|}{ девочки } & & \\
\hline Средняя & $8559 \pm 187$ & $9151 \pm 175$ & 2,31 & $<0,05$ \\
\hline Старшая & $9439 \pm 185$ & $10022 \pm 181$ & 2,25 & $<0,05$ \\
\hline Подготовительная & $13504 \pm 204$ & $14202 \pm 194$ & 2,47 & $<0,05$ \\
\hline
\end{tabular}

Проведение корреляционного анализа по выявлению связи показателей объёма двигательной активности и результатами в контрольных упражнениях, оценивающих уровень физической подготовленности дошкольников показал: 
- у мальчиков величина коэффициента корреляции между объёмом двигательной активности и результатом бега на 30 м возрастает с 0,843 для выборки средней группы до 0,911 для выборки подготовительной группы; у девочек аналогичные взаимосвязи имеют меньшую величину, 0,768 в средней группе и 0,832 в подготовительной группе;

- у мальчиков в аналогичных группах величина коэффициента корреляции между объёмом двигательной активности и результатом челночного бега на $3 \times 10$ м возрастает с 0,864 до 0,930 но несколько уменьшаясь с 0,814 до 0,806 у девочек;

- у мальчиков величина коэффициента корреляции между объёмом двигательной активности и результатом теста «прыжок в длину с места» возрастает с 0,825 в средней группе до 0,959 в подготовительной группе; у девочек аналогичная взаимосвязь характеризуется коэффициентом корреляции 0,872 и 894, соответственно, в названных группах;

- у мальчиков значение коэффициента корреляции между показателями объёма двигательной активности и результатами теста «сгибание и разгибание рук из виса лежа на низкой перекладине» снижается с 0,821 до 0,762, оставаясь достоверной, а у девочек - с 0,768 до 0,752;

- у мальчиков значения коэффициента корреляции между показателями объёма двигательной активности и результатами теста «подъем туловища за 30 сек» возрастают с 0,797 до 0,857, соответственно, для средней и подготовительной группы, а у девочек уменьшается с 0,812 до 0,739 для соответствующих выборок, сохраняя значимость коэффициента корреляции при уровне значимости $(\mathrm{p}<0,01)$.

Увеличение значений коэффициентов корреляции прослеживается для всех указанных тестов, что подтверждает возможность увеличения показателей физической подготовленности при помощи разработанной педагогической технологии, включающей традиционные и инновационные технологии физического воспитания, по увеличению объёмов двигательной активности у детей дошкольного возраста.

С возрастом у мальчиков влияние экспериментальной технологии на увеличение объёма двигательной активности возрастает, а у девочек сила связи увеличивается не столь значительно по сравнению с показателями мальчиков. Это может означать, что показатели физической подготовленности у мальчиков дошкольного возраста возрастают более значительными темпами по сравнению аналогичными показателями у девочек.

Наличие достоверных коэффициентов корреляции прослеживается для всех указанных тестов, что открывает возможность получения моделей для расчёта должных объёмов двигательной активности для детей дошкольного возраста.

Модель для расчёта должного объёма двигательной активности у мальчиков подготовительной группы семи лет имеет следующий вид:

$\mathrm{Y}=4736,9+(339,56 \times \mathrm{X} 1)+(106,02 \times \mathrm{X} 2)+(23,01 \times \mathrm{X} 3)+(126,28 \times \mathrm{X} 4)+$ $(143,11 \times \mathrm{X} 5)$,

где 4736,9 - расчётный коэффициент;

$\mathrm{X} 1$ - результат в беге на 30м;

$\mathrm{X} 2$ - результат в челночном беге $3 \mathrm{x} 10 \mathrm{M}$;

Х3 - результат в прыжке в длину с места;

$\mathrm{X} 4$ - результат сгибания и разгибания рук из виса лежа;

X5 - результат в тесте «подъем туловища в сед за 30 сек».

Расчёты для показателей модели должных объёмов позволили уточнить численные коэффициенты предлагаемой формулы для девочек подготовительной группы: 


$$
\mathrm{Y}=11949,99-(635,17 \times \mathrm{X} 1)+(279,86 \times \mathrm{X} 2)+(87,33 \times \mathrm{X} 3)-(239,31 \times \mathrm{X} 4)-
$$
$(295,27 \times \mathrm{X} 5)$.

Для проверки возможностей данных уравнений были выполнены расчеты должных объёмов двигательной активности у детей 7 лет, когда в качестве аргументов выступали показатели средних величин контрольных упражнений, у девочек и у мальчиков этого возраста. Величина относительной погрешности при использовании предложенных математических моделей находится в пределах $2 \%$.

Представленные данные позволяют заключить, что модели для расчёта должных показателей объёма двигательной активности могут успешно использоваться в процессе организации физического воспитания для детей, посещающих дошкольные образовательные организации.

$$
* * *
$$

1. Баландин В.А. Возрастные особенности динамики показателей физического развития, физической подготовленности и психических процессов детей 5-7 лет в период подготовки и адаптации к обучению в школе / В.А. Баландин, Ю.К. Чернышенко // Физическая культура: воспитание, образование, тренировка. - 2009. - № 3. - С. 24-29.

2. Коновалова Н.Г. Профилактика плоскостопия у детей дошкольного и младшего школьного возраста: Учебно-методическое пособие / Изд. : Учитель, 2015 г - с 63.

3. Михайлов Н.Г. Формирование подходов к системе непрерывного образования по физической культуре в ГОУ "Начальная школа - детский сад" / Н.Г. Михайлов, А.П. Матвеев // Теория и практика физ. культуры. - 2009. - N 6. - С. 58-64.

4. Никитушкин, В. Г. Метаучение о воспитании двигательных способностей: монография / В.Г. Никитушкин, Г.Н. Германов, Р.И. Купчинов. - Воронеж: Элист, 2016. - 506 с.

5. Рунова М.А. Двигательная активность ребёнка в детском саду: Пособие для педагогов дошкольных учреждений. Преподавателей и студентов педвузов и колледжей. - М.: Мозаика-Синтез, 2004. - С. 5 $-11$.

6. Столяров В.И., Бальсевич В.К., Мочёнов В.П., Лубышева Л.И. Модернизация физического воспитания и физкультурно-спортивной работы в общеобразовательной школе/Под общ. ред. докт. филос. наук, проф. В.И. Столярова. - М.: Научно-издательский центр «Теория и практика физической культуры», 2009. - 320 с.

7. Теория и методика физического воспитания и развития ребенка: Учеб. пособие для студ. высш. учеб. заведений / Эмма Яковлевна Степаненкова. - 2-е изд., испр. - М.: Издательский центр «Академия», 2006. - 368 с.

8. Филиппова С.О. Теоретические и методические основы физического воспитания и развития детей раннего и дошкольного возраста: Учебник для студ. учреждений сред. проф. образования / С.О. Филиппова, О.А. Каминский, Г.Г. Лукина и [др.]; под ред. С.О. Филипповой. - 7-е изд., доп. - М.: Издательский центр «Академия», 2015. - 320 с.

9. Чеченов Х.Д., Фетисов В.А. Информационно-аналитические материалы по теме «Спорт в школе» (подготовлены Аналитическим управлением аппарата Совета Федерации) // Спорт в школе: актуальные проблемы /Библиотечка журнала «Вестник образования России». - 2009. - №6. - С. 1323.

10. Astrand P.O., Rodahl K., Textbook whole physiology: physiological bases of development of children of preschool age and early school age. ofexersise. New York, 2008. - 691 p.

\section{Поляруш А.А. \\ От индустрии знаний - к методу познания}

Ачинский филиал Красноярского государственного аграрного университета

(Россия, Ачинск)

doi 10.18411/spc-04-02-2019-11

idsp sciencepublic-04-02-2019-11

Становящаяся ныне цивилизация, отличается от цивилизаций прошлого тем, что в центре её не проблема, как лучше выполнить те законы жизни, которые уже известны, а в чём состоят эти законы. И ответ уже зависит не только от объективных детерминантов, но от собственного человеческого выбора. В сущности, все ведущие школы социальной теории исходят из представления о том, что конкретный человек детерминирован в своём поведении, в своих психологических установках теми или иными внешними факторами - техническими, экономическими, социально- 
групповыми. Подход к детерминации в современных условиях должен быть более диалектичным и сложным. Современная цивилизация, оказавшаяся перед судьбоносным вопросом: «Быть или не быть... человечеству» (название книги Н.Н.по объективным законам развития, вынуждена возвести самое естественное, природное свойство человека - мысль - в ранг самых могущественных и эффективных сил планеты [5].

Перед лицом диффузного, хаотичного изобилия явлений, с одной стороны, постоянной флуктуации, изменения, возникновения и уничтожения, с другой стороны, нужно найти надёжный инструментарий для овладения действительностью и ориентации в мире. Этому требованию может удовлетворять только такая система, которая в состоянии упорядочить это хаотическое изобилие, что делает многообразие обозримым, вносит в него порядок и связь. Такой системой является диалектика наука о всеобщей связи.

В пылу нескончаемых реформ высшая школа отказалась от задачи выработки философского мировоззрения, углубила хаотизацию знаний; во-вторых, лишила их целостного философского основания, системности, что привело к обессмысливанию духовного пространства, превратив его в набор «информационных блоков».

Никакая специфическая познавательная способность не может должным образом отражать действительности, если она является частью целого, в котором все другие психологические способности искажены. Отказ от специфических характеристик педагогической деятельности даёт возможность вскрыть глубокую внутреннюю и необходимую связь учебного процесса со всеми без исключения областями культуры, выяснить место и роль учебного процесса в системе общечеловеческих ценностей.

Современное образования обречено на поражение, потому что закрепляет в молодом специалисте качества, давно утратившие свою общественно-историческую актуальность. Узко-профессиональные способности были востребованы в эпоху машинного производства, когда человек был средством производства, своеобразным механизмом.

Высшая школа, если она стремится воспитать высококлассного профессионала, т.е. интеллектуально развитую, диалектически мыслящую личность, личность уникальную, вбирающую в себя всю полноту определений мира, с объективной необходимостью вынуждена вооружить студента соответствующим методом мышления.

На смену индустрии знаний Коменского должна прийти школа, где формируется мыслящая личность.

За два века самое великое человеческое дело (Э.В. Ильенков) - дело формирования личности - не только не продвинулось ни на йоту, но, как видим, даже узаконивает безнравственные способы манипуляции человеческим сознанием (ибо обучение строится на противоестественных принципах), лицемерно называемые образованием.

Благие по выражению, но абсолютно пустые по содержанию, векторы реформируемого образования направлены лишь на изменение формы, т.е. внешней стороны предмета. Обнаружение отчуждённой формы есть рассудок. Разум же претендует на выражение целостности и единства бытия, на выражение его внутренних тенденций и интенций [4].

Ложные методологические принципы порождают «больную и странную» педагогическую проблему, как её обозначает Ильенков. Обыкновенно её формулируют как проблему «применения знаний в жизни, в практике», что равносильно требованию формирования «знаний, умений, навыков». Отсюда легко возникает представление, 
будто в составе человеческих способностей должна иметься особая способность какимто образом «соотносить» знание и его предмет. Если так, то должны, по-видимому, существовать известные правила такого соотнесения. В дидактике и пытаются решить проблему «применять знания в жизни» путём создания такой системы правил. В результате такая система правил становится настолько громоздкой, что начинает скорее мешать, чем помогать делу, превращаясь в дополнительный источник ошибок и неврозов. Зубрёжка, возведённая в величайшую степень, становится причиной резко ухудшающегося здоровья обучающихся [3].

В самом деле, знание в точном смысле этого слова есть всегда знание предмета. Определённого предмета, ибо невозможно знать «вообще», не зная определённой системы явлений. В таком случае сама фраза о трудностях применения знаний к предмету становится абсурдной.

Организовать процесс усвоения знания как знания предмета, как конкретное целое - это значит - учить мыслить. Авторы способа диалектического обучения А.И. Гончарук и В.Л. Зорина, разработали теорию обучения, основанную на центральной категории диалектической логики - противоречии, что служит основой построения педагогической технологии [2].

Методологической основой педагогики может быть только диалектика.

Против плоского характера эмпирического мышления, на котором и выстроена вся современная дидактическая система, боролся Э.В. Ильенков за теоретический подход к вещам. Те или иные абстракции должны выводиться в учебном процессе его субъектами из их объективной природы, т.е. из противоречий природы, - иначе они остаются непонятыми и формально усвоенными [3].

Как только противоречие становится сознательной формой мышления, предмет становится ясным для сознания, а движение абстракций - формой сознательного, логически последовательного выражения самого предмета. Только при соблюдении этого условия можно говорить об осмысленном усвоении знаний, а осмыслить - значит подвергнуть вещь теоретическому анализу [4].

Чтобы присвоить себе всеобщую универсальную способность мышления, необходимо в учебном процессе перерабатывать представление в понятие. Такой метод всегда есть движение всеобщего в особенном. Есть всегда обнаружение всеобщего в особенном. Гегель впервые исследовал диалектическую природу понятия. Как актуально звучит мысль Гегеля, высказанная ещё в начале XIX века: «Понятие надо вывести, а не произвольно или механически взять, не «раскрывая», не» уверяя», а доказывая, исходя из противоречий... в них всё развитие» [1].

Главным критерием эффективного образования мы полагаем сформированность у субъектов образовательного процесса системы выводных знаний (понятий) через осмысление всеобщего принципа противоречия и принятия его как основного элемента культуры мышления современного человека (содержательный компонент) на основе моделирования объектов познания (формальный компонент).

Человечество никогда не ставит перед собой неразрешимых задач, налицо всегда задачи, которые могут быть разрешены средствами, уже имеющимися в материальном и духовном мире.

$$
\text { *** }
$$

1. Гегель Г.В.Ф. Наука логики. В 3-х томах. Т. 1. М.: Мысль, 1970. 501 с.

2. Гончарук А.И. Концепция школы XXI века. Красноярск, 2002.

3. Ильенков Э.В. Философия и культура - М.: Политиздат, 1991. 464 с.

4. Лобастов Г.В. К философским основаниям педагогики В.В. Давыдова // Вопросы философии. 2005. № 5. C. $45-61$.

5. Моисеев Н.Н. Быть или не быть ... человечеству. Ульяновский Дом печати, 1999. — 288 с. 


\section{Скрынников Н.П.}

\section{Кодекс чести офицера: история и направления развития}

ФГКВОУ ВО "Рязанское гвардейское высшее воздушно-десантное ордена Суворова дважды краснознаменное командное училище имени генерала армии В. Ф. Маргелова" Министерства обороны Российской Федерации (Россия, Рязань)

doi 10.18411/spc-04-02-2019-12

idsp sciencepublic-04-02-2019-12

В конце XX-начале XXI веков начала меняться геополитическая картина мира. Державы, обеспечивавшие существование однополярного мира, под действием социально-экономических и политических условий перестали считаться таковыми. Служба в армии многими рассматривается как возможность быстро подняться по карьерной лестнице, пользуясь положенными благами и привилегиями: бесплатное государственное обеспечение, медицинское обслуживание, т.д. Командиры частей и подразделений несут ответственность за адаптацию новичков к непривычным для них условиям, сами офицеры из младшего командного состава называют себя отцами и наставниками молодых воинов. Поэтому вопрос о том, что из себя представляет в настоящее время понятие офицерской чести и кодекса чести офицера требует особого рассмотрения. Это особенно важно в связи со словами бывшего министра обороны РФ С. Иванова, сказанными еще в 2005 году: "России нужны просвещенные, интеллигентные офицеры, которые на деле стали бы специалистами, способными выработать новые требования к личному составу, военным кадрам будущего и к организации их обучения. Нам необходим дух инноваций в офицерском корпусе" [4].

Воины всегда были особой группой, имевшей свои профессиональные требования, привычки и нормы поведения и морали. В древности, когда еще не было понятия офицерского звания, был функционал - отвечать за физическую и моральную подготовку новобранцев, обучать их хитростям ведения боевых действий, выживать в сложных природных условиях без пищи и воды. Каждый, кто подтверждал свою репутацию славного бойца, пользовался особым почетом и уважением соплеменников, потому как выжить в столь суровом окружении можно было только с помощью подготовленных людей. Командира выбирали сами воины, отдавая предпочтение самым сильным и способным вести за собой, бесстрашных в бою, держащих данное слово. Поэтому, уважая собственный выбор, они беспрекословно слушались своего предводителя. От последнего при разделе военной добычи требовалось быть справедливым, чтобы не обделить тех, кто действительно внес достойный вклад в общую победу на поле боя. Поэтому командир должен был уметь видеть всю картину боя целиком: и со стороны, и как ее участник. Чтобы поддержать боевой дух воинов, командир должен был выделяться на поле внешне, для чего у каждого народа были свои атрибуты: знамена, яркие перья, отличавшееся боевое облачение.

Вместе с тем, как считают исследователи, само понятие офицерской чести остается «вещью в себе», содержание и смысл которой не раскрыты до конца. По этой причине достаточно сложно предсказать, на какие нормы и моральные принципы должны опираться люди, относящие себя к офицерам [7].

Армейские порядки периода древности были просты и суровы: каждый воин приносил клятву верности верховному правителю, который воплощал в себе и царственную особу, и весь народ, проживающий на данной территории. Защищать и воевать за царя означало воевать за свою родную землю, и наказание за нарушение обета верности было только одно - немедленная смерть. Родных такого казненного ожидала незавидная участь, вплоть до изгнания из царства, поскольку согласно законам рода, они несли ответственность за дурное воспитание своего родича. До появления царств командирами, выполнявшими функции офицеров, могли быть только 
отличившиеся в бою воины. Родоплеменные отношения способствовали тому, что командовать отрядом мог только соплеменник, чужаков не признавали. Впрочем, если он мог показать свое воинское мастерство в присутствии других, как только его назначали главой отряда, причем для этого требовалось принять вызов самого сильного воина из вверенного ему отряда, ему прощали его происхождение.

В странах Европы (Англии, Франции, Германии, Испании, др.), начиная с периода Великих географических открытий, возросла потребность в квалифицированных военных кадрах. От солдат и их командиров требовалось не только слепое подчинение, но и умение анализировать местность, знакомиться с обычаями и системой верований потенциальных врагов, что позволяло быстрее побеждать их в столкновениях. Офицеры, выделившись в отдельную категорию военных, стали отделяться от простых солдат, подчеркивая тем самым свое превосходство над ними. В первую очередь это было вызвано тем, что претендовать на звание офицера могли только представители богатых и знатных родов. Позднее, когда начали появляться династии потомственных военных, это различие стало более значительным. Быть офицером означало на всю жизнь быть связанным долгом чести, быть обязанным хранить верность воинскому Уставу, чего простые смертные старательно избегали. Даже в годы, когда речь шла о защите родной земли, простые люди, представленные ремесленниками, крестьянами и другими сословиями, никогда не называли себя солдатами или воинами. Они могли исполнить свой гражданский долг и вернуться к привычной мирной жизни, что для профессиональных военных было недопустимо. За оскорбление офицера в русской армии Петром Первым была придумана система наказаний [9], что нельзя рассматривать как нечто принципиально новое. Столь жесткое отношение к виновникам объяснялось тем, что оскорбление бросало тень не столько на оскорбленного офицера, сколько на весь офицерский состав. Поэтому и в русской, и французской, и прусской армиях последствия такого действия можно было убрать только публичным извинением или собственной кровью.

В британских войсках отношение к офицерам было двояким: с одной стороны, они были представителями знати, способные платить за свое обучение приличные деньги. С другой - они получали знания, которые у гражданских специалистов отсутствовали. Впрочем, характерно и то, что несмотря на все знания, искусство ведения военных действий им приходилось постигать методом проб и ошибок, так как такой дисциплины не преподавалось ни в одном военном королевском колледже [10]. Особенно спорным моментом является сдача экзаменов на право получения офицерской должности по таким предметам, как история Священных писаний, грамматический разбор простых предложений с французского и латинского языков. Положение осложнялось и тем, что целенаправленной подготовки по-настоящему квалифицированных военных кадров не проводилось, что подтвердили итоги англобурской и Первой Мировой войн.

Количество подготовленных к началу Первой Мировой войны британских офицерских кадров с лихвой превысило качество, что привело к их дискредитации. Однако престиж профессии военного никуда не делся по простым причинам - звание офицера давало возможность продвижения по социальной лестнице за счет заключения выгодных браков. Дезертиров метили особым образом - разрывали им рукава мундира, за что в военное время можно было поплатиться не только свободой, но и жизнью.

Что касается российской армии, здесь дело обстояло несколько иначе. Благодаря усилиям Петра Первого, была создана регулярная армия, в которой было положено отслужить 25 лет, прежде чем выходить в отставку. Если в начале своего становления офицерами были выходцы из дворянских семей, щепетильно относившиеся к чести своего рода и мундира, то по мере увеличения численности армии соответственно возросла численность офицерского корпуса. Однако в нем значительно увеличилась 
доля тех, кто изначально не принадлежал к дворянскому сословию с его понятиями о личной и корпоративной чести.

Офицер был обязан держать свое обещание, и выражение «слово офицера» впервые стало использоваться в конце 19 века для обозначения этой профессионально значимой черты. О том, насколько сами офицеры серьезно относились к собственным словам, говорят следующие факты, рассказанные в исторических хрониках:

- Петр Нестеров, первым в истории авиации исполнивший боевой таран во время Первой Мировой войны, дал слово офицера сбить вражеский самолет и сдержал его, заплатив за это собственной жизнью;

— Будущий царь Александр III, оскорбивший офицера, получил от него письмо с просьбой принести извинение за такой неблаговидный поступок, обещая в случае отказа покончить с собой. Поскольку наследник не счел нужным извиняться, то офицер застрелил себя, чтобы сдержать свое обещание [8].

Создание регулярной армии поставило офицеров перед задачей пожизненного служения Родине и следования строгому уставу чести, т.е. четких предписаний допустимого и непозволительного поведения. Так, офицерам запрещалось посещать места с сомнительной или откровенно дурной славой: варьете, питейные заведения, мелкие кинематографы, места для азартных игр [7]. Независимо от того, где он находится и с кем общается, офицер должен был придерживаться высоких моральных принципов: вести себя просто и непринужденно, не заискивать и не быть снобом, быть вежливым и немногословным, не бахвалиться и не подвергать без надобности риску жизни окружающих. Особенно серьезно офицеры относились к пустословам и трусам, презирая их за неумение держать язык за зубами и быть не в состоянии отвечать за свои слова и поступки.

В Японии вопрос о конкуренции между армией и флотом был вызван несоответствием требованиям времени. Так, японские генералы армии считали правильным придерживаться старинных методов военных действий: набрасываться скопом на противника, игнорируя тот факт, что мечи и сабли не достают врагов, использующих огнестрельное оружие. Солдат набирали по принципу «Чем фанатичнее и необразованнее -тем лучше», ведь такой вояка не станет даже раздумывать над смыслом приказа и постарается его выполнить, невзирая на огромные человеческие потери. В отличие от армии, флот отдавал предпочтение образованным, владеющим иностранными языками и легко обучаемым городским парням. Они умели просчитывать ситуацию в бою и использовать выгоды дальней и ближней стрельбы из пушек и винтовок, благодаря чему флот действовал более успешно в сражениях [2]. К главным пунктам кодекса чести японских офицеров можно было отнести следующие:

- Япония прежде всего;

- Император - тот, кому служит каждый японец и считает это за высшее благо;

— Умереть во имя императора и Японии почетно;

- Любой приказ сюзерена выполняется беспрекословно.

С таким кодексом вопрос о спасении раненых на поле боя практически не ставился. Напротив, раненые солдаты и самураи просили добить их или оставить умирать, чтобы они могли исполнить веления кодекса Бусидо, уходя в мир иной с чистой совестью - ведь они погибли с честью [1].

Характерно, что практически во всех писаных и неписаных кодексах военных, особенно офицерского состава, прописывается один момент. Это - осознание риска для собственной жизни при выполнении боевой задачи. При этом офицер не должен делить мирных жителей на чужих и своих, не должен применять против них оружия и своих навыков. Офицер должен понимать, что его обязанности в период военных действий 
означают спасение для одних и гибель для других, и одна из его задач заключается в том, что руководить действиями солдат с целью уничтожения живой силы противника. Но даже в этом случае предписывалось не проявлять излишнюю жестокость, смерть должна была быть быстрой и не мучительной.

Автором кодекса чести российского офицера называют ротмистра B. Кульчицкого, который в 1904 году во время русско-японской войны собрал советы, обращенные к молодым офицерам. Благодаря их содержанию, наставления Кульчицкого можно считать именно кодексом чести. Так, он выделяет разные типы поведения в отношениях с разными людьми: сослуживцами, стоящими выше по званию, дамами и лицами, с которыми напряженные отношения. Рекомендуется быть сдержанным на слова и чувства, доказывать свою правоту не силой, а уметь убеждать разумными доводами, уважать чужое мнение, не поддаваться эмоциям и не писать или говорить сгоряча. Даже будучи с человеком в ссоре, в присутствии других необходимо поздороваться с ним, для чего вполне достаточно подать ему руку. Допустив в чемлибо ошибку, настоящий офицер не боится признать этого. Для него самое важное - с честью нести свое высокое звание, не давать повода для пересудов и сплетен, не участвовать в чьих-то интригах.

Однако стоит отметить, что советы В. Кульчицкого многое почерпнули из принятых еще в правление Петра Первого Воинского Устава в 1771 году. Равно как и «Кодекс чести члена Союза советских офицеров», принятый в начале 90-х годов XX века. Красной нитью по всем названным документам проходит общая мысль: патриотизм, верность слову, забота о ближнем. Среди главных качеств офицера называются честность, храбрость, скромность, благородство, самообладание [6].

Как отмечает А.Е. Холманских, честь может трактоваться двояко: как честь внутренняя, субъективная, и как честь внешняя, объективная. Внутренняя представляет собой чувство самоуважения, осознания собственной порядочности и меры соответствия внутреннему идеалу. Что касается внешней чести, то ее следует рассматривать как определяемую потребностью человека оставаться членом какойлибо общности, соблюдая принятые в ней нормы поведения и разделяя ее идеалы. Отказ от этого означает риск оказаться отвергнутым данным сообществом, поэтому офицерское достоинство следует рассматривать как основывающееся на добром имени и репутации. В 1894 году, несмотря на запреты со стороны правительства, дуэли среди офицеров за право отстоять свою честь с оружием в руках стали показываться как необходимость. Офицеры имело право носить оружие в любой обстановке, кроме приема у государя. Это дало возможность обособить и подчеркнуть статус офицеров как элиты войск, поднять престиж офицерства. За тем, чтобы офицеры вели подобающий им образ жизни и не позорили честь мундира следили специально созданные офицерские суды чести, членами которого были люди с безупречной воинской репутацией. Эту традицию позже переняли в советские времена, когда в 1946 году было принято решение о создании аналогичных структур в рядах действующей армии. В 1973 году стали действовать суды чести для солдат сверхсрочной службы, прапорщиков и мичманов. В отличие от японских солдат и офицеров, русские военные, согласно кодекса чести, обязаны были служить Отечеству, а не правителю в лице царя или кого бы то ни было. Именно этим и объясняется участие высокопоставленных офицеров в восстании декабристов: они посчитали деспотичную царскую власть угрозой для Отечества, говоря, что присягали на верность не государю, а родной стране.

В наши дни требования к соблюдению кодекса офицерской чести изменились настолько, что возникла необходимость создания нового кодекса. Однако здесь возникла трудность такого рода: несмотря на то, что понятие чести используется везде, где только можно, нет его единой, общепринятой трактовки. У каждого рода войск и даже у отдельных профессий имеются свои кодексы чести: 
Судьи Российской Федерации (от 21.10.1993)

Таможенника Российской Федерации (от 3.09.1996)

Сотрудника органов внутренних дел (пр.№501, 1993) [7].

Если раньше молодые люди выбирали офицерскую долю по идейным соображениям и стремились соответствовать принятым в их среде идеалам, то в настоящее время мы наблюдаем несколько иную картину. После службы в армии большинство возвращается в мир гражданских профессий и отношений, где нет трепетного, как прежде, отношения к своим обязательствам и определенному образу жизни. Не последнюю роль в этом играет и то, что ни в одном официально принятом документе нет понятия «честь» [5]. Это привело к тому, что в 2010 году Третье Всеармейское совещание армии и флота было посвящено обсуждению и формированию новых норм корпоративной этики российского офицера [3].

Как отмечает В.А. Иноземцев, суды чести офицеров актуальны в плане того, что они должны привлекать к ответственности не за нарушенные правовые нормы, а нормы морали и нравственности. Причем для этого необходимо «держать руку на пульсе», чтобы разрабатываемые положения Кодекса чести и уставы судов чести соответствовали современным реалиям.

$$
* * *
$$

1. Бусидо. Кодекс чести самурая. https://templar-code.com/kodeks-chesti/natsionalnye-kodeksy/283busido-kodeks-chesti-samuraya

2. Война японской армии против японского флота http://alternathistory.com/vojna-yaponskoj-armiiprotiv-yaponskogo-flota/

3. Готовится к принятию Кодекс чести российского офицера https://bport.com/news/item/33525.html?nomobile=1 от 11.01.2010.

4. Иванов С. Армии и флоту нужны «офицеры XXI века» / публ.от 01.09.2005 https://www.rbc.ru/society/01/09/2005/5703c5019a7947dde8e0ce19

5. Иноземцев В.А. Перспективы создания кодекса чести офицеров российских Вооруженных Сил http://natural-sciences.ru/ru/article/view?id=30601

6. Моторкин И. Офицерская честь. http://www.memorial.krsk.ru/Work/Konkurs/13/Motorkin1/0.htm

7. Офицерская честь и правовые нормы. https://cyberpedia.su/13xe4e3.html

8. Сыромятников Н. «Слово офицера»: что на самом деле оно означает. http://russian7.ru/post/slovooficera-chto-na-samom-dele-ono-o/

9. Х Холманских А.Е. Кодекс чести русского офицера. Автореф.диссерт.канд.ист.н. М., 1999.

10. Шендыгаев Д.И. Военное образование офицеров британской армии и флота на рубеже XIX-XX вв. //Вестник Брянского Государственного Университета. №3, 2018. С.161-168.

\section{Старостина А.Н.}

\section{Начертательная геометрия как феномен человеческой культуры}

ГБОУ ВО Нижегородский государственный инженерно-экономический университет (Россия, Княгинино)

doi 10.18411/spc-04-02-2019-13

idsp sciencepublic-04-02-2019-13

Начертательная геометрия как наука была создана в конце XVIII в. великим французским ученым Гаспаром Монжем. Величайшей его заслугой является обобщение всей теории о методах изображения пространственных тел и создание единой математической науки об ортогональном проецировании. Отдельной книгой курс начертательной геометрии Монжа был опубликован в 1798 г. После выхода в свет этой книги интерес к начертательной геометрии стал широко распространяться за пределами Франции.

Примечательно, что вскоре после рождения новой науки в Петербурге было основано первое в России высшее транспортное учебное заведение - Институт корпуса инженеров путей сообщения (3 декабря 1809 г.), в стенах которого была создана отечественная начертательная геометрия как наука. Питомцы этого института 
внесли большой вклад в развитие геометрических методов изображения, в теорию и практику начертательной геометрии.

Создателем института и его первым ректором стал крупный механик и строитель, ученик Гаспара Монжа Августин Августович Бетанкур, потомок короля Канарских островов. Бетанкур еще в 1784 г. в Париже слушал лекции Монжа о конструировании и классификации машин и механизмов, познакомился с первыми идеями начертательной геометрии. Поэтому неудивительно, что после Франции курс начертательной геометрии впервые в России был включен в учебную программу только что созданного института.

В 1816 г. профессор института К. И. Потье выпустил первый в России (издан Академией наук) учебник по начертательной геометрии на французском языке, а уже в 1821 г. выходит в свет учебник на русском языке по этой дисциплине, написанный питомцем института профессором Я. А. Севастьяновым. Большой вклад в развитие отечественной начертательной геометрии внесли профессора путейского института $\mathrm{H}$. П. Дуров, А. Х. Редер, Н. И. Макаров и др [1].

Одну из важнейших страниц в историю развития отечественной инженерной графики вписал учащийся института, автор классических работ по начертательной геометрии и ее приложениям, профессор В. И. Курдюмов. Его основной заслугой является издание классического курса «Начертательная геометрия», состоящего из четырех томов общим объемом более 1 тыс. страниц (издавался этот труд в течение пяти лет, с 1890 по 1895 г.). Перу В. И. Курдюмова принадлежат более 50 научных и учебных трудов, 14 из них посвящены методам изображения и начертательной геометрии.

Очевидно, большая инженерная и научная деятельность явилась причиной того, что В. И. Курдюмов и начертательную геометрию рассматривал как науку, призванную решать чисто прикладные задачи. Это ему принадлежат слова, определяющие саму суть начертательной геометрии: «Если чертеж является языком техники, одинаково понятным всем народам, то начертательная геометрия служит грамматикой этого мирового языка, так как она учит нас правильно читать чужие мысли и излагать на нем наши собственные мысли, пользуясь в качестве слов только одними линиями и точками как элементами всякого изображения» [2].

Выдающийся ученый и педагог, В. И. Курдюмов своими прекрасными лекциями зародил в душе студента Н. А. Рынина любовь к начертательной геометрии, которую он пронес со студенческих лет до последних дней жизни. «Должен обратить внимание, - вспоминал Н. А. Рынин, - еще на один важный фактор: развитие моего воображения и фантазии. В этом отношении мне сильно помогли мои усиленные занятия по начертательной геометрии... Как убедил меня последующий опыт, инженер должен обладать кроме знания своей специальности еще и техническим воображением и фантазией, которые помогают ему ориентироваться среди неожиданных, новых и нетрафаретных условий своей деятельности и создавать новые формы, явления и инженерные сооружения, до него ранее не бывшие» [3]. С 1901 г., после окончания института Рынин стал преподавать эту дисциплину в старейшем транспортном институте.

Он написал более 50 научных работ по основным разделам начертательной геометрии и по праву считается основоположником советской инженерной графики.

Хотя известный французский геометр Шаль в 1852 г. и говорил, что «начертательная геометрия лишь исполняет, а не творит», однако последующие успехи еe применения и развитие еe на базе проективной геометрии, номографии, кинематографии показали ошибочность этого взгляда и выдвинули ее наравне с другими прикладными науками в числе приемов, которыми человек может пользоваться для открытия новых законов и методов расчета различных сооружений [4]. 
Начертательная геометрия является звеном, соединяющим математические науки с техническими. Возникший за последние годы ряд новых технических наук аэросъемка, киноперспектива, стереография и т. п. - выводит целый ряд новых положений на основе графического решения поставленных задач. Особенно сильный толчок к развитию начертательной геометрии и получению при помощи нее многих научных открытий дало появление проективной геометрии и номографии [4].

Нельзя, пожалуй, назвать ни одного раздела начертательной геометрии, которым бы не занимался и в который бы не внес существенный научный вклад Н. А. Рынин. Им были написаны фундаментальные учебные курсы и научные труды по всем основным разделам начертательной геометрии: «Методы изображения» (1911, 1916 гг.), «Проекции ортогональные» $(1911,1916,1918,1935$ гг.), «Перспектива на плоскости» (1912 г.), «Аксонометрия» (1913, 1922 гг.), «Сборник задач по начертательной геометрии» (1916, 1923 гг.), «Перспектива» (1918 г.), «Проекции с числовыми отметками» (1922 г.), «Кинематография» (1924г.), «Номография» (1924, 1934 гг.), «Киноперспектива» (1936 г.) и «Начертательная геометрия» (1939 г.).

Еще в первых научных работах, посвященных теории проектирования ледорезов, определению освещенности помещений и расчету пространственных металлических конструкций, Н. А. Рынин широко использует геометрические методы решения прикладных задач. Проектирование ледорезов [5] он рассматривал как комплексную позиционную задачу начертательной геометрии на построение пересечений и касаний различных сложных поверхностей. Полученные им пять теорем о взаимном касании поверхностей второго порядка представляли большой интерес не только для проектирования ледорезов, но и для дальнейшего развития теоретических основ важнейшей геометрической проблемы - построения плавных обводов.

Создавая новую теорию расчета освещенности проектируемых помещений [6] H. А. Рынин успешно использовал методы центрального и параллельного проецирования и теорию теней. В работе «Расчет шарнирных колец из жестких элементов», которая была представлена Н. А. Рыниным на соискание ученой степени адъюнкта и успешно защищена в 1909 г., он оригинально использовал метод стереографических проекций для изображения и определения геометрических параметров пространственных конструкций. И значительно позднее, во многих научных работах, посвященных воздухоплаванию и космонавтике, он также использовал геометрические методы: графическое изображение эволюции в воздухе как одиночного самолета, так и целых эскадрилий [7], построение в ортогональных проекциях специальных карт траекторий движения планет [8] и пр.

Одной из главнейших заслуг Н. А. Рынина является развитие проективного направления в начертательной геометрии. Мысль о том, что все существующие в начертательной геометрии методы изображения (ортогональные и аксонометрические проекции, перспектива и тени, проекции с числовыми отметками) можно изложить на основе теории проективной геометрии, высказывалась им еще в 1907 г. [9]. Он считал, что если принять за основу проективные соответствия (коллинеарные преобразования), то теория изображения получит большую общность и стройность. Н. А. Рынин убедительно доказал, что «...для правильного и ясного изучения начертательной геометрии необходимо изучение аналитической и проективной геометрии, и в особенности второй, и что все эти три вида геометрии тесно связаны между собой» [9]. В 1937 г. он заканчивает фундаментальный труд (объемом около 40 печатных листов), в котором излагает все существующие методы изображения с позиций проективной геометрии [10].

Как и многие другие разделы геометрии, он пытался не только использовать проективную геометрию как теоретическую основу графической геометрии, но и применить ее для решения конкретных прикладных инженерных задач. Так, на основе 
проективной геометрии он разрабатывает графические методы решения задач аэрофотосъемки [11].

Позднее, в 1924 г., в работе «Кинематография» [12] Н. А. Рынин посвящает теории киноперспективы целую главу, в которой формулирует и доказывает 14 теорем, составляющих основу этого метода изображения. В 1936 г. выходит в свет его капитальная работа «Киноперспектива» [13], в которой изложены теоретические основы линейной перспективы, а также киноперспективы как науки, изучающей законы изменения формы и размеров изображений движущихся в пространстве фигур в функции времени. С точки зрения начертательной геометрии особый интерес представляют найденные $\mathrm{H}$. А. Рыниным геометрические зависимости между перспективным изображением предмета и перемещением его в пространстве (вращение, движение вдоль главного луча и параллельно картине).

Характеризуя теоретические работы Н, А. Рынина, в первую очередь следует отметить высокий научный уровень изложения основных разделов начертательной геометрии. С этой позиции наиболее показательным является его фундаментальный курс «Начертательная геометрия: Методы изображения» [14]. Особенно широко рассмотрены теоретические основы всех существующих видов перспективных проекций (перспектива линейная, панорамная, купольная, плафонная, воздухоплавательная, кабинетная, обратная, радиальная, а также перспектива на цилиндрических сводах и кривых поверхностях). Здесь же Н. А. Рынин впервые в отечественной литературе излагает теорию перспективных рельефных изображений и проецирования из нескольких центров (бицентральная перспектива и стереография).

Следует также отметить, что в этой работе автор впервые высказывает мысль о возможности графическими способами отображать фигуры многомерного пространства «при помощи проектирования их в пространство трех измерений» [14].

О широкой эрудиции Н. А. Рынина в области начертательной геометрии, обширных знаниях литературы свидетельствует богатая библиография, которая приводится во многих его трудах. Так, в упомянутой работе «Начертательная геометрия: Методы изображения» указана библиография отечественных и иностранных авторов по начертательной геометрии в количестве 717 (!) наименований.

Особенно показателен в этом отношении его уникальный «Сборник задач по начертательной геометрии» [7], в котором приведено 10 тыс. задач из самых различных областей науки и техники. И неудивительно, что многие из его учебных курсов через несколько лет после издания становились библиографической редкостью.

С именем Николая Алексеевича связано и появление в нашей стране первой книги по истории начертательной геометрии. Понимая важность изучения истоков начертательной геометрии как науки, он в 1938 г. издает монографию «Материалы к истории начертательной геометрии», в которой излагает историю развития основных методов изображения [15].

Историю развития ортогональных проекций Н. А. Рынин разделяет на четыре этапа. Первый этап — с древнейших времен до 1795 г. Это первые попытки изображения пространственных фигур в ортогональных проекциях немецким художником А. Дюрером (начало XVI в.), французским математиком Р. Декартом (середина XVII в.) и, особенно, французским инженером А. Фрезье (середина XVIII в.).

Второй этап - с 1795 по 1822 г. Началом этого периода Н. А.Рынин считает выход в свет знаменитого труда французского геометра и основоположника начертательной геометрии Г. Монжа «Начертательная геометрия» («Geometrie Descriptive»), в котором впервые была изложена стройная теория ортогональных проекций.

Третий этап - с 1822 г. до 30-х годов XX в. Начало этого периода бурного развития проективной геометрии связано с появлением сочинения французского военного инженера и математика Ж. Понселе «Исследование проективных свойств 
фигур» («Traite des proprietes projectives des figures»), которое было опубликовано в Париже в 1822 г. (написан этот труд был в 1813-1814 гг. в России, в Саратове, где Ж. Понселе находился в плену после разгрома войск Наполеона). Четвертый этап - c начала 30 -х годов XX в. Н. А. Рынин связывает с широким внедрением начертательной геометрии вообще и ортогональных проекций в частности в науку и технику.

Возникновение метода проекций с числовыми отметками автор относит к XVI в., когда впервые стали применяться кривые одинакового уровня для изображения поверхностей. Начало развития аксонометрических проекций он связывает с появлением военной перспективы как косоугольного проецирования на горизонтальную плоскость и в качестве примера приводит план Московского Кремля (1610 г.). Основоположником теории проекций с числовыми отметками и аксонометрии в России Н. А. Рынин называет А. Х. Редера («Теория проекций с числовыми отметками или дополнительными числами», 1855 г., и «Об изометрической проекции», 1855 г.).

Рассматривая историю развития перспективных проекций, Николай Алексеевич выделяет семь основных этапов.

1. Наблюдательная перспектива со времен Евклида.

2. Геометрическая перспектива. Работа Пьеро делла Франческа «О живописной перспективе» (1458 г.) и появление на ее основе панорамной, плафонной и купольной перспективы.

3. Аналитическая перспектива. В середине XVIII в. разрабатываются способы построения перспективных изображений, использующие аналитические формулы и зависимости, полученные еще Ж. Дезаргом в середине XVII в.

4. Проективная перспектива. В методы построения перспективных изображений начиная с 1822 г. внедряются теоремы проективной геометрии Ж. Понселе.

5. Стереоскопическая перспектива. В конце XIX в. разрабатываются способы построения изображений с двух точек зрения.

6. Физическая и физиологическая перспектива. В начале $\mathrm{XX}$ в. с целью приближения к реальным зрительным ощущениям формы, освещенности и света в теорию перспективных изображений внедряется учение физики о свете и цвете.

7. Кинематография и киноперспектива. C начала XX в. изучается влияние на перспективные изображения движения предмета и точки зрения (аппарата).

Здесь следует заметить, что научные труды Н.А. Рынина, являясь прекрасным обобщением и достойным продолжением и совершенствованием всех научных трудов его предшественников, подняли начертательную геометрию на более высокую научную ступень и открыли новые страницы во многих еe теоретических и прикладных разделах.

Николай Алексеевич считал, что начертательная геометрия призвана не только создавать графические методы решения задач пространственной геометрии, но и совершенствовать методы изображения пространственных тел на плоскости. Наивысшее предназначение этой науки он видел в создании новых методов геометрического мышления, геометрического моделирования, в развитии у человека пространственного воображения, инженерной эрудиции и фантазии. В одной из своих работ Н. А. Рынин писал, что начертательная геометрия «является наивысшим средством развития той таинственной и мало поддающейся изучению точными науками способности человеческого духа, которая зовется воображением и которая является ступенью к другой царственной способности - фантазии, без которой почти не совершаются великие открытия и изобретения» [16].

Научные исследования по начертательной геометрии, казалось бы, должны вселять оптимизм. Однако, выполняемые исследования, на наш взгляд, далеки от начертательной геометрии, их уровень достаточно низкий. Зачастую, пользуясь терминологией В.И. Курдюмова, они представляют низкопробные «перепевы» 
классических исследований, а иногда и откровенный плагиат. В стране нет ни одного издания по начертательной геометрии, входящих в перечень ВАК, и чтобы иметь возможность опубликовать статьи, необходимо им зачастую искусственно придавать прикладную направленность. Заниматься фундаментальными научными исследованиями в области начертательной геометрии в условиях рынка, стало невыгодно, так как их результаты не приносят сиюминутной прибыли.

Нельзя начертательную геометрию рассматривать только как основу машиностроительного черчения. Она является полноценным разделом математики. Вырабатывая способность по плоскому изображению видеть пространственные фигуры, студент преодолевает стереотипы мышления и восприятия, обретая духовность. Начертательная геометрия, не являясь сегодня модной наукой, переживает далеко не лучшие времена. Но уже в ближайшем будущем ситуация должна измениться. Например, описание наноструктур невозможно без ее методов. Было бы неправильным считать, что содержание начертательной геометрии как учебной дисциплины со времен Г.Монжа должно оставаться без изменений. Начертательная геометрия - развивающая наука, и вряд ли здесь уместен консерватизм. С другой стороны, необходимо предотвратить попытки замены дисциплины компьютерной или машинной графикой. Компьютеры должны помогать в усвоении дисциплины. Нужно оставить в покое и саму начертательную геометрию как феномен человеческой культуры и ее название, под которым она триумфально шествовала на протяжении двух веков.

На наш взгляд, изымать начертательную геометрию из учебных планов высших учебных заведений было бы верным способом уничтожения инженерного образования. Необходимо сохранить те ценные знания, которые человечество добывало столетиями. И, выражая надежду на то, что начертательная геометрия еще долгое время будет полезной в деле подготовки образованных инженеров, хотелось бы завершить статью словами известного ученого И.Ф. Шарыгина о геометрии в целом, а, следовательно, и о начертательной как ее части: «Геометрия, стоявшая у колыбели человеческого разума, может помочь сегодня человеку сделать еще один скачок в своем развитии. Интеллектуальном, духовном и нравственном. Надо не упустить эту возможность» [17].

$* * *$

1. Тарасов Б. Ф. Методы изображения в транспортном строительстве. Л., 1987. С. 223-232.

2. Курдюмов В. И. Курс начертательной геометрии: Проекции ортогональные. СПб., 1895. С. 86.

3. Как я сделался профессором воздушных сообщений. 1933. Рукопись. Арх. Ан СССР, ф. 928, оп. 1, ед. хр. 157.

4. Начертательная геометрия. Л., 1939. 448 с, 918 л. черт.

5. Ледорезы. СПб., 1903. 143 с, 151 л. черт.

6. Дневной свет и расчеты освещенности помещений: (Руководство К рациональному проектированию световых отверстий в различных сооружениях и к определению степени освещения). СПб., 1908. 156 с, 117 л. черт.

7. Сборник задач по начертательной геометрии. Пг., 1923. 628 с, 3400 л. черт.

8. Межпланетные сообщения. Вып. 9. Астронавигация, летопись и библиография. Л., 1932. 218 с, 93 л. черт.

9. Значение начертательной геометрии и сравнительная оценка ее методов. СПб., 1907. 89 с, 75 л. черт.

10. Начертательная геометрия на основе проективной. 1937. Рукопись. 1000 с.

11. Проективная геометрия и применение ее в аэросъемке. Л., 1931. 159 с, 93 л. черт.

12. Кинематография. Л., 1924. 300 с, 328 л. черт.

13. Киноперспектива: (Теория перспективы движущихся форм и применение перспективы в кинотехнике). Л., 1936. 160 с, 234 л. черт.

14. Начертательная геометрия: Методы изображения. Пг., 1916. 264 с, 367 л. черт.

15. Материалы к истории начертательной геометрии: (Библиография, биографии, факты, хронология). Л., 1938. 112 с, 43 л. черт.

16. Начертательная геометрия. Отдел 3. Проекции с числовыми отметками. СПб., 1907. 16 с, 37 л. черт.

17. Шарыгин И.Ф. Нужна ли школе 21-го века Геометрия?// Матем. просв. - 2004.- №8. С. 37-52. 
Тюнькова И.А.

\title{
Организация и проведение краеведческих игр со школьниками
}

\author{
Иркутский государственный университет
}

(Россия, Иркутск)

doi 10.18411/spc-04-02-2019-14

idsp sciencepublic-04-02-2019-14

С 2014 года в городе Иркутске по инициативе Департамента образования МКУ «ИМЦРО» и городской общественной организацией «Краеведческий клуб «Иркутск Форт Росс», совместно с кафедрой географии, безопасности жизнедеятельности и методики ПИ ИГУ проходит краеведческая игра «Вслед за Солнцем», являющаяся проектом, призванным стимулировать активное краеведение в городе.

Цель: выявление и сопровождение одаренных обучающихся, развитие творческого потенциала и профессиональной компетентности педагогов в области естественнонаучных дисциплин и активного краеведения, активизация интеллектуального потенциала талантливых школьников, повышение интереса к изучению географии, биологии, экологии.

Задачи:

- Пропаганда здорового образа жизни и активного отдыха.

- Стимулирование к познанию окружающего пространства.

- Повышение интереса к активным формам краеведения.

- Организация тематического сообщества на основе постоянных инициативных участников.

Активное краеведение - вид интеллектуального досуга, сочетающий краеведческую работу, городское ориентирование и игровые моменты. Это одновременно и спортивное соревнование и интеллектуальная викторина на знание своего города. Спортивная составляющая заключает в себе скорость прохождения маршрута, умение оптимально составить стратегию прохождения контрольных пунктов, навыки спортивного ориентирования на местности. Интеллектуальная часть раскрывается в содержании стартов: маршрутные задания включают вопросы на знание старинных названий улиц города, выдающихся исторических мест, городской инфраструктуры, экологического состояния городской среды.

Краеведческая игра «Вслед за Солнцем» организуется для обучающихся $9-11$ классов в рамках городского краеведческого интеллектуального и познавательного марафона «Созвездия Байкала».

Методическое обеспечение игры с 2016 года осуществляет кафедра географии, безопасности жизнедеятельности и методики Педагогического института ИГУ. Преподавателями кафедры накоплен необходимый теоретический и практический опыт в организации, подготовке, методическом сопровождении различных конкурсов. Имеющийся научный и учебно-методический потенциал в течение последних лет реализуется при проведении мероприятий для школьников и учителей города и области [1]. Для проведения игры разрабатывается Положение, определяется тематика соревнований, с учетом которой прокладываются маршруты и составляются задания на каждый этап. Определяются критерии оценивания, осуществляется судейство на этапах.

Участие в игре как организаторы принимают студенты, обучающиеся по профилям бакалавриата «Безопасность жизнедеятельности - География», «Безопасность жизнедеятельности - Химия», «Безопасность жизнедеятельности Иностранный язык» и магистратуры «Географическое образование», «Комплексная безопасность образовательных организаций». Они помогают разрабатывать методические материалы, работают судьями на этапах и оценивают результаты. Также, каждую команду школьников при прохождении по маршруту сопровождают кураторы из студенческого спасательного отряда «Барс», следящие за безопасностью и строгим соблюдением правил. Вовлечение студентов в различные формы совместной работы 
кафедры с образовательными организациями позволяет реализовывать деятельностный подход в подготовке бакалавров и магистрантов к профессиональной деятельности [2].

В 2018 году командные соревнования школьников были организованы в пятый раз и посвящались 100 -летию Иркутского государственного университета. Традиционно соревнование проводится в начале учебного года, в первое воскресенье сентября. Команда от каждой образовательной организации получает картосхему с контрольными точками и маршрутный лист с заданиями на каждый этап. Выполнение заданий на контрольных пунктах предусматривает не только всесторонние знания о своем населенном пункте, но и умения пользоваться компасом, масштабом, условными знаками и городскими ориентирами. Обязательно используются загадки, описания, по которым нужно определить следующий объект.

Возрастающая популярность данного мероприятия подтверждается увеличением количества участников игры.

Таблица 1

Динамика участников игры «Вслед за Солнцем»

\begin{tabular}{|c|c|c|c|c|}
\hline Год проведения & $\begin{array}{c}\text { Количество } \\
\text { команд }\end{array}$ & $\begin{array}{c}\text { Количество } \\
\text { участников }\end{array}$ & $\begin{array}{c}\text { Количество } \\
\text { студентов }\end{array}$ & $\begin{array}{c}\text { Количество } \\
\text { преподавателей }\end{array}$ \\
\hline 2015 & 18 & 123 & 7 & 16 \\
\hline 2016 & 26 & 184 & 30 & 23 \\
\hline 2017 & 36 & 290 & 54 & 36 \\
\hline 2018 & 32 & 175 & 36 & 34 \\
\hline
\end{tabular}

Правила и порядок проведения представлены в Положении о проведении краеведческой игры «Вслед за Солнцем». Информационная поддержка размещается на сайтах департамента образования города и координаторов проекта. Участники игры получают сертификаты, а победители и призеры отмечаются грамотами и призами.

Следует отметить, что привлечение к организации мероприятия городских общественных организаций дает возможность расширить рамки традиционного школьного краеведения, сделать его более интересным, познавательным, и общественно значимым. Школьное краеведение выступает универсальным педагогическим средством, помогающим формировать и развивать познавательный интерес обучающихся, их мотивационную сферу, активизировать учебную деятельность, воспитывать разносторонне развитого человека, патриота своей земли.

$$
* * *
$$

1. Тюнькова И.А. Возможности и перспективы проведения межрегиональной олимпиады школьников «Географический олимп». //Современные исследования социальных проблем.№3-2 (59). Красноярск: Изд-во Научно-Инновационный центр, 2016.-с.209-214.

2. Роговская Н.В., Тюнькова И.А.. Проблемы и перспективы взаимодействия высшей школы и научных организаций для профессиональной подготовки кадров в области географических наук. // Современные исследования социальных проблем, 2016, № 7(63), с. 64-78, ISSN 2218-7405 (online)

\section{Ушакова И.А. \\ Управление психоэмоциональным состоянием иностранных студентов средствами физической культуры}

ФГБОУ ВО «Волгоградский государственный медицинский университет» Минздрава РФ

(Россия, Волгоград)

doi 10.18411/spc-04-02-2019-15

idsp sciencepublic-04-02-2019-15

Проблеме изучения психофизиологического состояния человека и его влияния на различные виды деятельности в настоящее время посвящено большое количество научных исследований. Неблагоприятное психофизиологическое состояние, как 
правило, ухудшает характеристики деятельности, отрицательно влияет на здоровье и самочувствие человека.

На современном этапе весьма актуальны различные аспекты регуляции психологического состояния, являющиеся объектом не прекращающегося всестороннего изучения. Также актуален поиск способов, помогающих выявить, реализовать, мобилизировать возможности организма человека [1].

В процессе учебы учащиеся испытывают значительное нервно-психическое напряжение, состояние «эмоционального стресса». Практика и научные исследования показывают, что студенты часто бывают подвержены волнению, выходящему за пределы нормального эмоционального возбуждения. Имея различные формы проявления (нарушения координации движений, «провалы» памяти, ухудшение физического состояния и работоспособности, обильной потливости, сухости в горле, тремор рук и др.), это психическое состояние, особенно «эмоциональная напряженность», оказывают огромное влияние на эффективность профессиональной деятельности. В связи с этим, для профилактики «эмоционального стресса» необходимо использовать весь комплекс современных возможностей - педагогических, психологических, медицинских.

Значение физической культуры и спорта в устранении негативных сторон «эмоционального стресса» отмечается в ряде научных исследований. При обучении в одном и том же учебном заведении обнаружена существенная разница как в исходных величинах, так и в порядке вегетативных сдвигов на экзаменах у студентов спортсменов по сравнению со студентами, не занимающихся спортом. Частота пульса и тремора у физкультурников ниже, чем у остальных, а по данным опроса в период экзамена у них наблюдается и меньший уровень волнения. Это объясняется тем, что систематические тренировки и участие в соревнованиях делает человека более эмоционально устойчивым.

В результате занятий физическими упражнениями исчезают отрицательные эмоции, наблюдаются позитивные биохимические сдвиги, развиваются необходимые двигательные навыки, происходит адаптация организма к физической нагрузке и воздействию окружающей среды.

В 2018 году в одной из серий исследований нами изучалось влияние занятий физической культурой на психофизиологическое состояние зарубежных студентов. Выяснялось воздействие на состояние нервно-мышечного аппарата и умственную работоспособность. Регистрация интересующих нас параметров проводилась в начале и в конце осеннего семестра. В исследованиях приняли участие 20 студентов-юношей первого курса, имевших не ниже $60 \%$ посещаемость занятий по физической культуре (1-я группа) и 20 - имевших 98\% посещаемость основных занятий и активно принимающих участие во внеучебных спортивных мероприятиях (2-я группа). О функциональном состоянии нервно-мышечного аппарата студентов судили по данным теппинг-теста (количество точек за 30 с) и метода определения точности мышечных усилий (\% отклонения от заданной величины). Устойчивость внимания определяли по методике Иванова-Смоленского с использованием корректурных буквенных таблиц. Уровень функционирования ЦНС определялся по результатам компьютерной тестпрограммы «Око».

На конечном этапе исследований показатель точности мышечных усилий в 1 -ой группе улучшился с 14,0+3,6 до 13,8+3,7\% (p<0,05), во 2-ой - с 13,6+3,3 до 13,0+3,2\% $(\mathrm{p}>0,05)$. Итоговое значение теппинг-теста в 1-ой группе практически не изменилось, во 2-ой - отмечалось достоверное улучшение на $11,5+6,4 \%$. Результаты тестирования по методике Иванова-Смоленского свидетельствовали об увеличении объема прослеживаемой информации в первой группе на $16,4+8,5 \%$, во второй - на $29,6+14,2 \%$, количество ошибок в прослеженной информации уменьшилось соответственно с $38,0+6,6$ до $32,0+4,5 \%(p<0,05)$ и с $29,0+5,5$ до $21,0+5,8 \%(p>0,05)$. 
В обеих группах снизился показатель психического утомления по тесту Люшера (норма < 10 у.е.) с 8,3+1,4 до 7,5+0,6 у.е. $(\mathrm{p}<0,05)$ и с 7,9+0,8 у.е. до 7,0 +0,9 у.е. $(\mathrm{p}<0,05)$. Уровень ситуационной тревожности по Спилбергеру (норма $<13$ у.е.) в первой группе практически не изменился и был равен $10,40+1,1$ у.е., во второй отмечено снижение показателя с 9,7+0,8 до 8,2+0,6 у.е. (p>0,05).

На притяжении всего периода исследований в занятия с зарубежными студентами первого курса включались упражнения, позволяющие уменьшить психоэмоциональное напряжение:

- дыхательная гимнастика (в сочетании с расслаблением мышечного корсета).

Дыхание, включающее короткий вдох, продолжительный выдох и последующую непродолжительную задержку дыхания, приводит к общему снижению тонуса центральной нервной системы, урежению пульса. Доказано, что рационально используемые дыхательные упражнения в сочетании с пониженным тонусом скелетных мышц, влияют на уменьшение избыточного возбуждения, формирование оптимальной готовности к будущей деятельности.

- мимическая гимнастика.

Расслабление мышц лица понижает уровень подавленности и тревоги. Улыбка вызывает чувство уверенности в себе, благодаря чему уменьшается внутреннее напряжение, легче переносится психический дискомфорт.

- массаж «антистрессовых точек».

Раздражение механорецепторов, находящихся на кистях рук, приводит к ощущению тепла, что благотворно воздействует на весь организм. Массаж рук помогает расслабляться, снимать напряжение. Вместе с тем, энергичный массаж мизинца содействует снятию психического перенапряжения, нервного утомления.

Результаты проведенных исследований позволили внести коррективы в учебный процесс по физической культуре с иностранными студентами, разработать новые подходы в управлении психоэмоциональным состоянием на начальном этапе их адаптации к новым условиям проживания в инонациональной среде.

$$
* * *
$$

1. Гуревич П. С. Психология и педагогика : учебник для академического бакалавриата / П. С. Гуревич. - 2-е изд., перераб. и доп. - М. : Издательство Юрайт, 2017. - 479 с.

2. Физическая культура в социокультурной и профессиональной адаптации студентов медицинского вуза: монография /И.А. Ушакова, под ред. В.Б. Мандрикова. - Волгоград: Изд-во ВолгГМУ, 2016. 209 c.

\section{Хмелевская Я.А. \\ Учебная мотивация как один из критериев эффективности учебного процесса}

Московский государственный областной университет (Россия, Мылтищи)

doi 10.18411/spc-04-02-2019-16

idsp sciencepublic-04-02-2019-16

\section{Аннотация}

Данная статья раскрывает понятие мотивации и стимула, рассмотрены основные методы мотивации учащихся. Выделены условия формирования у обучащихся полноценной мотивации. Выделены виды мотивы, связанные с трудовой деятельностью: мотивы, включающие в себя удовлетворение потребностей человека связанных с трудом, мотивы выбора профессии, мотивы выбора места работы. Мотивация к процессу обучения неоднозначна и может быть связана с различными изменениями, происходящие со студентами в процессе обучения. В статье рассмотрены 
приемы и методы мотивирования студентов. Проведенный анализ проблемы позволил установить, что мотивация является эффективным способом управления и улучшения учебного процесса.

Ключевые слова: мотив, мотивация, стимул, мотивация учебной деятельности, учебный процесс.

\section{Abstract}

This article presents the notion of motivation and stimulation, considering the principal methods of motivation for the students. Pointing out the conditions of the formation of the motivation of the students.

Highlighting the types of motives related to the employment: motives, the selfsatisfaction, the human needs related to work, the motives of the choice of the profession and the place of work.

The motivation during the studies is ambiguous and can interfere with numerous changes, that happen during the learning process of the students.

In the article are presented methods of motivation for students.

The analyse of the problems allows to say, that motivation appears from effective ways of management and improve the learning process.

Key words: motive, motivation, stimulus, motivation of educational activity, educational process.

Мотивация учебно-познавательной деятельности учащихся является одной из фундаментальных педагогических проблем современности. Ее следует отнести к обязательным условиям современного образовательного процесса. Отношение к значимости воспитания мотивации учащихся к обучению зависит от уровня профессиональной подготовки педагога, его мастерства и профессиональной культуры.

Мотивация (от лат. moveo - двигаю) ныне рассматривается как реализация мотива в конкретной деятельности в процессе выбора возможных действий, направленных на достижение определенных целей. Мотив - побуждение или стремление к достижению цели и осознания действия по ее достижению [5, с. 217].

В свете деятельного подхода, при анализе мотива, акцент делается на содержании обучения, что особенно существенно для выбора учеником профильных предметов и профессии в будущем.

Следовательно, в учебном процессе необходима такая организация учебной деятельности, при которой бы росла познавательная активность учащихся как условие их успешности, их выборочная мотивационная направленность, без которой невозможно усвоение сложных, особенно физико-математических или естественных знаний.

Мы должны учитывать, что модель мотивации и социального поведения определяется взаимодействием трех составляющих: ценностей, компонентов компетентности и социальных установок. Чтобы оценить силу мотивации индивида к определенной деятельности (в нашем случае отношение ученика к обучению), необходимо учесть все три компонента и выяснить, считает ли человек эту деятельность важной, то есть ценной для себя, стремится проявить свою компетентность в выполнении поставленной задачи и встретит ли он поддержку со стороны тех, чье мнение для него важно, то есть от социального окружения. Все эти компоненты играют решающую роль в процессе оценки ее мотивации и компетентности [8, с. 261].

Формирование мотивации - сложная дидактическая проблема. Исследование ученых-педагогов, наблюдения и выводы учителей-практиков свидетельствуют об общем снижении мотивации к обучению среди учащихся младших классов, так и среди старшеклассников и даже среди студентов ВУЗОВ. Снижение мотивации у младших 
школьников частично связано с тем, что необязательно игровая деятельность в дошкольном возрасте (когда ребенок играет по желанию) меняется обязательной (даже принудительной) учебной деятельностью.

Мотивами учебной деятельности у учеников младшей школы становится стремление понять явления окружающей природы, выяснить связи, причины возникновения. При этом формируется умение группировать, обобщать, применять результаты обобщения [6, с.195]. Для развития мотивации к обучению учителям можно рекомендовать: подбирать интересную информацию, создавать позитивный эмоциональный настрой школьников, выявлять известные закономерности в новых ситуациях, разнообразить методы и приемы работы с учениками, определять оптимальный уровень индивидуальной сложности задач, дозированной помощи, раскрывать цели изучения всей темы и каждого урока. Стимулировать мотивацию к учебно-познавательной деятельности необходимо за счет:

a) применения задач, которые активизируют;

б) создание ситуации успеха для каждого ученика;

в) предоставление конструктивной помощи в случае затруднений; г) поощрение проявлений любознательности, сильных сторон личности ученика и т. п. [7, с. 40].

У подростков мотивация к учебно-познавательной деятельности усиливается, ведь меняется соотношение между конкретно-образным и абстрактным мышлением в пользу последнего. Развивается способность к умственным экспериментам. Умение оперировать гипотезами во время решения интеллектуальных задач является важнейшим достижением подростков для анализа окружающего мира.

У старшеклассников мышление становится системнее, знания трансформируются в когнитивную модель мира, служащую основой для формирования мировоззрения. Мотивы к учебно-познавательной деятельности постепенно превращаются на формирование соответствующих потребностей в приобретении знаний и выборе сначала профильных предметов, а затем и профессионального самоопределения [4, с. 176]. При этом постановка учеником реалистичных целей, потребностей и их достижения предопределяет мотивационное здоровье личности [3, с. 201].

Мотивационные тенденции ученика заключаются в выборочной мотивационной направленности по содержанию учебных предметов и в повышенном восприятии определенной учебной информации, которая является интересной и нужной ученику.

В школьный период важным результатом образования становится не только объем полученных знаний, но и развитие личности, в частности ее мотивационной сферы, что является важной задачей школы. Ведь учебно-познавательная деятельность - процесс, направленный на овладение знаниями, умениями и навыками, способствует развитию личности при условии сознательного, мотивированного отношения ученика к содержанию деятельности. Поэтому роль школьных психологов и учителей заключается в своевременном диагностировании мотивов деятельности. При этом в основе организации учебной деятельности по усвоению знаний приоритетным должно быть понимание ценностной значимости важных для ученика знаний. То есть к структуре учебно-познавательной деятельности должен входить (в контексте формирования учебной мотивации к усвоению определенных знаний) компонент. В его состав входят мотивация, позитивное отношение к любимым предметам, потребность в их познании [1, с. 169].

Итак, мотивация является одним из показателей учебно-познавательной

деятельности. Желание приобрести определенную профессию предопределяет мотивированное, сознательное отношение к обучению. То есть наличие личностного смысла в приобретении знаний - одно из условий формирования мотивационной готовности к выполнению определенной учебно-познавательной деятельности и в 
будущем к выбору профессии. Чтобы помочь каждому ученику в профессиональной самореализации, школьному психологу и классному руководителю нужно:

a) периодически проводить диагностирование уровней мотивации к обучению, а также анкетирование и консультирование учащихся, родителей, учителей;

б) вести разъяснительную и просветительскую работу о необходимости приобретения соответствующих профильных знаний;

в) применять методики, повышающие мотивационную готовность учащихся к учебно-познавательной деятельности (проективные методы, проблемный подход и т. д.).

Без удовлетворения учеников своим обучением сложно сформировать самый высокий осознанно-рефлексивный уровень мотивационной готовности, при которой ведущую роль играют ценности саморазвития, профессионального самоопределения и самореализации [7, с. 98].

Как известно, есть ученики умные от природы, которые имеют высокую мотивацию к обучению, стремятся к самообразованию и самосовершенствованию, то есть любят учиться. Это, как правило, одаренные дети, у которых познавательный мотив устойчив на всех этапах школьного обучения [3, с. 203]. Они имеют высокий уровень мотивации, поэтому усилия учителя должны быть направлены на такое:

а) создание условий для обеспечения их саморазвития;

б) поиск адекватных видов деятельности, необходимых для построения индивидуального развития ученика;

в) развитие способности ориентирования также на цели, которые выходят за пределы потребностей настоящего. Построение подростком своей временной перспективы является свидетельством появления мотивации к сознательному обучению, саморегуляции, проявлению тенденции к саморазвитию личности.

Отдельного внимания заслуживают дети, склонные к исследовательской и научной деятельности, особенно в сфере естественных наук, где необходимо проведение опытов и решения экспериментальных задач. Детская потребность в исследовательском поиске заложена природой, ведь ребенок рождается исследователем, знакомясь с окружающим миром. Психологическое развитие таких детей происходит как процесс саморазвития, методы организации их исследовательской деятельности являются специфическими. В частности, это

удачный отбор темы исследования, разработка развернутого плана проекта, одобрение его руководителем, креативность ребенка, умение находить и решать проблему. Если ученик увлекается естественными предметами, то у него надо развивать еще и наблюдательность, настойчивость, терпение, способность оценивать природные факторы и др.

Выше отмечалось, что ученые-дидакты, психологи и учителя-практики признают факт снижения познавательного интереса современных учащихся как важного мотива учения (с 25\% до 5\%) [2, с.211]. На развитие познавательного интереса могут положительно повлиять:

а) социальные мотивы (одобрение окружающими успеха, обязательности и т. п);

б) мотивы достижения успеха (желание получить хороший результат);

в) престижные мотивы (стремление быть первым и лучшим);

г) познавательные мотивы, связанные со стремлением к получению новых знаний и умений;

д) мотивы удовлетворения от результата процесса познания, которое наступает.

Интенсивность познавательной ситуации зависит от возраста детей: в начальной школе она эпизодическая, ситуативная. У учащихся основной школы познавательные потребности часто «аморфны», не ярко выражены. У старшеклассников они становятся стержневыми, связанными с выбранным профилем обучения и будущей профессией. 
Если потребность в знаниях и внутренние мотивы учащихся к обучению не совпадают с внешне заданным содержанием, то происходит утрата интереса к знаниям, нежелание усваивать сложное содержание обучения.

Познавательную активность, своеобразный познавательный «аппетит» можно рассматривать как состояние готовности к осуществлению учебной деятельности. Она зависит, прежде всего, от познавательных мотивов, потребностей, которые возникают и актуализируются в проблемной ситуации, что становится импульсом к поисковой познавательной активности.

Актуализация познавательной деятельности, то есть познавательная активность возникает в том случае, если появляется потребность в тех знаниях, которые крайне необходимы для решения проблемы. Тогда и возникает внутренний познавательный мотив (потребность в конкретных знаниях, необходимых именно для этого человека), что способствует реализации замысла. То есть зарождение познавательного мотива происходит как реакция на интеллектуальное затруднение, возникающее в процессе деятельности. Итак, познавательный мотив, как толчок к достижению цели, является внутренним мотивом [2, с. 220].

В процессе изучения естественных предметов, которые являются преимущественно экспериментальными, рассмотрение учебного материала должно происходить ка анализ проведенных опытов, наблюдений (а не наоборот, когда с помощью опыта учитель подтверждает определенное теоретическое положение), как выяснение причин того или иного физического или химического явления. При этом определяется причинно-следственная зависимость между явлениями и фактами, возникает их осознание. Тогда такие знания становятся фундаментальными, мировоззренческими. Они способствуют пониманию необходимости гармоничного сосуществования человека с природой (коэволюции), умного природоиспользования.

В случае решения проблемных ситуаций также усиливается мотивация учебнопознавательной деятельности учащихся. Примером такой мотивации является выяснение противоречий между приобретенными и новыми знаниями.

В частности, в процессе ознакомления с явлением изомерии обучающиеся с удивлением узнают, что свойства веществ зависят не только от их состава (о чем они знали ранее), но и от строения (новая для них информация). Подобные примеры есть и у других естественных предметах. Например, в курсе физики в процессе рассмотрения парадоксов науки, фактов или явлений, которые противоречат друг другу. В частности, противоречие между научным фактом и жизненным опытом обучающиеся наблюдают во время выяснения причин того, почему шуба «греет», и тому подобное.

Если определенные знания для ученика жизненно важны, то тогда и возникает внутренняя познавательная мотивация. В таком случае лучше, если учитель не дает готовую информацию, а советует источники для самостоятельного решения проблемы.

Мотивация к обучению возникает и в процессе выяснения противоречий между ожидаемым и реальным результатом опыта. Например, от действия фенолфталеина на раствор соды его цвет (против ожиданий учеников) меняется на малиновый (щелочная среда), хотя раньше они знали, что растворы солей образуются вследствие реакции нейтрализации и поэтому должны быть нейтральными. Так в их сознании возникает понимание явления гидролиза солей.

Способом возникновения учебно-познавательной мотивации является также рассмотрение противоречий между результатами правильно и неправильно выполненных упражнений (например, если нарушена последовательность выполнения или другое условие). Совместное определение причин возникших противоречий, то есть анализ неудач в процессе выполнения опытов также усиливает мотивацию учебнопознавательной деятельности учащихся. Сначала возникает недоумение, потом интерес и, как следствие, - мотивация к обучению. 
Аналогичное случается и в случае противоречий между разными взглядами (в основном ученых), оценками определенного факта или события (обычно исторической естественной) [5, с.73]. Например, повышение среднегодовой температуры атмосферы Земли, то есть возникновение «парникового эффекта» одни ученые связывают с выбросами топливными предприятиями в атмосферу избыточного углекислого газа, а другие, наоборот, выбросы этого газа связывают с повышением температуры вод Мирового океана, ведь, как известно, растворимость газов в воде с повышением температуры от нагрева Солнцем уменьшается, и, как следствие, углекислый газ из воды попадает в атмосферу. Повышение учебной мотивации в подобных случаях происходит во время выяснения вопросов, что является причиной и что является следствием этого природного явления.

Побуждение к появлению учебных мотивов, до выяснения причин определенного явления или факта может вызвать и ситуация сомнения. Например, благородные (инертные) газы было найдено еще при жизни Д. Менделеева, но уже после открытия периодического закона и периодической системы химических элементов. Так казалось, что периодический закон терпит крах, потому что где же их надо было разместить в таблице химических элементов? Размышления над этим вопросом рассеивает сомнения относительно справедливости периодического закона.

Итак, познавательная мотивация формируется в процессе разрешения противоречий. При этом развиваются мышление учеников и их способности.

Как известно, мотивация к обучению и содержание учебного материала взаимосвязаны, ведь интерес формируется на изучаемом содержании учетом эмоционального отношения ученика к определенному содержанию. Саморазвитие способностей к поиску истины развивает логическое мышление, помогает раскрытию потенциальных возможностей каждого ученика, дает ему возможность почувствовать радость открытия [4, с. 180].

По объему информации проблемное обучение несколько уступает информационному, однако лучше возбуждает мнение учащихся, формирует мотивацию к размышлению, что особенно важно для проведения экспериментов с естественных предметов. Поэтому задача учителя состоит в том, чтобы не подсказывать выводы и умозаключения, а лишь будить учебную мотивацию к решению поставленной проблемы.

В процессе формирования учебных понятий противоречия могут возникать и на грани отраслей их применения, и при условии повышения уровня усвоения содержания. Например, на уроках математики в основной школе обучающиеся узнают, что параллельные прямые не пересекаются (по Евклиду), а в старшей школе им становится известно, что через кривизну пространства параллельные линии могут пересекатьс). Или еще пример: изучая химию в основной школе, ученики узнают о постоянстве состава веществ, то есть о дальтониках.

Аналогично в седьмом классе ученики убеждены в том, что щелочи - это вещества, в которых атомы металлов связаны с гидроксогруппами, а вот в старших классах они узнают, что щелочи - вещества, которые связывают протоны.

Итак, с мировоззренческих позиций определения понятий на высшем уровне должно стать естественным итогом изучения свойств определенного объекта, закономерным выводом из процесса усвоения разносторонних внутренних связей и целостности системы, в которую входит определенное понятие, и последующее его обобщение. Умение создавать и использовать определенные ситуации для влияния на систему мотивов личности является важным компонентом педагогического мастерства.

Резюмируя, отметим, что усвоение знаний и умений на современном компетентностном уровне может происходить и при условии минимального участия учителя. А вот без активного участия самих учащихся процесс усвоения фундаментальных, мировоззренческих знаний на уровне современных требований 
невозможны. Поэтому следует стимулировать учеников к познавательной деятельности, создавать мотивы сознательного отношения к обучению. Только при таких условиях возможна самореализация учащихся в жизни, их адаптация в социуме.

Наиболее значимой для эффективности учебной деятельности является мотивация, обусловленная интеллектуальной инициативой и познавательными интересами ученика. Настоящий учитель должен разнообразить формы работы так, чтобы у каждого ученика возникало желание учиться и самовоспитываться. Надобно воспитывать положительные мотивы к обучению, как к ответственному, интересному и радостному труду. И если верить М. Остроградскому, что «хорошие учителя создают хороших учеников», то в будущем ученики хороших учителей станут настоящими людьми.

\section{$* * *$}

1. Белоусова Т.Н. Исследования и проекты: что снижает мотивацию школьников к познанию / Т.Н. Белоусова, М.А. Мазниченко // Народное образование. - 2010. - № 8. - С. 169-175.

2. Блинова Е.Р. Мотивация учебно-познавательной деятельности школьников с помощью контекстной задачи / Е.Р. Блинова // Народное образование. - 2010. - № 6. - С. 210-220.

3. Зеленина Е.Б. Одаренный ребенок: как его воспитывать и обучать? / Е. Б. Зеленина // Народное образование. - 2010. - № 8. - С. 201-206.

4. Идиатулин В.С. Принцип проблемности в учебном процессе / В.С. Идиатулин // Народное образование. - 2010. - № 8. - С. 176-181.

5. Кондаков И.М. Психология: иллюстрированный словарь / И.М. Кондаков. - СПб.: Прайм-Еврознак, 2003. $-512 \mathrm{c}$.

6. Овчинникова О.Н. Старшие подростки: мотивационная готовность к учебе и познанию: в поиске оптимальных условий / О.Н. Овчинникова, Т. М. Чурекова // Народное образование. - 2010. - № 2. C. 195-199.

7. Педагогический энциклопедический словарь / глав. ред. Б. М. БимБад; редкол.: М.М. Безруких, В.А. Болотов, Л.С. Глебова [и др.]. - М.: Большая российская энциклопедия, 2002. - 528 с.

8. Равен Дж. Компетентность в современном обществе: выявление, развитие и реализация / Дж. Равен; пер. с англ. - М.: Когито-Центр, 2002. - 396 с.

\section{Ширинов М.К.}

Специфические особенности дидактических принципов в совершенствовании взаимосвязанности и непрерывности преподавания предмета "Природоведение"

Институт переподготовки и повыщения квалификаџии руководящих кадров и специалистов системы народного образования имени А.Авлоний (Узбекистан, Ташкент)

doi 10.18411/spc-04-02-2019-17

idsp sciencepublic-04-02-2019-17

\section{Abstract}

This article discusses the features of didactic principles in enhancing the interconnectedness and continuity of teaching the subject of "Natural History" in the field of education and the training of specialists in primary education.

Reference words and concepts: integrity, continuity, stability, consistency, conformity, didactics, natural sciences and teaching methods.

Повышение качества и эффективности начального образования на основе научно обоснованных идей, то есть ожидаемого результата, если оно будет реализовано на конкретной основе, основанной на конкретной концепции. Поэтому обучение является важным фактором формирования и совершенствования личности на основе комплексного, личностного и компетентного подхода в начальном образовании.

При подготовке учителей начального образования к профессиональной педагогической деятельности преподается предмет «Природоведение и методы его преподавания» (название учебного плана в действующем учебном плане) по направлению начального образования педагогических вузов. Целесообразным является 
то, что студенты будут иметь глубокое понимание современных знаний, в частности, в систематическом овладении природными знаниями, опытом и навыками, а также своей способностью направлять свои навыки, основанные на их знаниях естественных наук, на более низких уровнях образования.

«Природоведение» систематизирует различные явления и процессы в природе через развитие объективного знания и его влияния. Природоведение изучает природу с помощью наблюдений и экспериментов, в результате получается система научного познания естественного и научного облика мира. Целью естествознания является изучение, анализ и определение явлений и процессов в природе.

При изучении природоведения студенты должны тщательно освоить дидактические принципы. Известно, что дидактика в педагогических науках имеет дидактические принципы для всех предметов, которые имеют дидактические принципы в улучшении взаимосвязанности и непрерывности преподавания «Природоведения».

Дидактика - концепция теории образования, которая учит принципам теории преподавания, методам преподавания, формам обучения и основным понятиям в педагогике.

Значит, дидактика отвечает на такие вопросы, как «нимага ўқитиш?», «зачем учить?»и «как учить?».

Дидактика служит основой для методики преподавания каждого предмета, наряду с определением общих законов и принципов обучения.

Теория активизации знаний студентов по дидактике очень близка к теории проблемного образования. Основная идея теории деятельности заключается в повышении активности студентов в специально организованной учебной среде. Теория развитой деятельности - это саморегулируемая деятельность по обучению процессу обучения, обучению и применению (проблемного и репродуктивного) обучения. На основе этих законов могут быть выражены следующие теоретические принципы, которые практически важны.

В целях обеспечения того, чтобы совокупность активаторов(средств активизации), содержание образования, формы и методы обучения, а также как самостоятельный процесс, они должны соответствовать следующим требованиям:

- стимулирование и развитие у студентов мотивации на всех этапах обучения;

- совершенствование механизмов, позволяющих учащимся устанавливать свои собственные цели и побуждать их планировать свою дальнейшую деятельность;

- Предоставление образовательных и интеллектуальных навыков в обработке информации;

— повысить физическую, этическую и волевую силу для достижения целей обучения студентов;

- Обеспечение того, чтобы учащиеся могли оценивать свою учебную деятельность посредством контроля и самоуправления в образовательном процессе. Если эти правила будут соблюдены, эффективность преподавания и обучения возрастет.

История дидактических принципов показывает, для того чтобы учителя достигали намеченных целей в проведении урока не тратя много сил и времени, несколько поколений ученых потратили немало сил в поисках совокупности дидактических принципов, это и стало причиной их создания.

В результате многолетних исследований и дискуссий необходимо учитывать важность системы нижеследующих дидактических принципов в преподавании педагогики, то есть «Природоведения»: 
1) осознанность и активность - способность студентов быть информированными и активно вовлеченными в процесс обучения;

2) дальновидность - эффективное использование разнообразных выставочных инструментов в обучении, основанных на принципе «лучше один рах увидеть, чем сто раз услышать»;

3) систематизация и регулярность - предоставление знаний в определенной системе и постоянно;

4) укрепление - предоставлять знания на понятном для студентов языке и закреплять их повторением;

5) понятность - знания должны быть всем ясны и быть одинакового уровня для всех;

6) научность - давать знания на основе имеющихся у детей знаний;

7) единство теории и практики -

показать, что теоретические знания применимы на практике, то есть связаны с жизнью и деятельностью.

Эти принципы служат для улучшения взаимосвязанности и непрерывности преподавания предмета «Природоведения», обогащая его смысл. 


\section{РАЗДЕЛ ІІ. ПСИХОЛОГИЯ}

\section{Баринова Е.В. Методы психической саморегуляции}

Тольяттинский государственньій университет (Россия, Сызрань)

doi 10.18411/spc-04-02-2019-18

idsp sciencepublic-04-02-2019-18

На сегодняшний день к числу самых распространенных и наиболее разработанных методов ПСР можно отнести: аутотренинг, БОС-технологию (биологическую обратную связь), медитацию, прогрессивную релаксацию. Все эти методы применяются для снижения напряжения и достижения состояния релаксации, помогая тем самым бороться со стрессом.

Кратко рассмотрим каждый из методов, их особенности и области применения.

Аутогенная тренировка была разработана в 30-е гг. XX в. немецким психиатром И. Шульцем. Суть метода заключается в осуществлении регулирования внутренних процессов посредством внушения или самовнушения определенных словесных формул. Классический аутотренинг, включает в себя несколько основных упражнений, оказывающих влияние на определенную область человеческого организма: мышцы, кровеносные сосуды, сердце, дыхание, брюшные органы и голову. Регулярные занятия АТ развивают у тренирующегося навыки произвольного вызывания ощущения тяжести и тепла в конечностях и брюшной полости, чувства прохлады в области лба, регуляцию сердечного ритма и дыхания. АТ может использоваться в комплексе с поведенческой терапией, ароматерапией, физическими и дыхательными упражнениями. Возможность сознательно влиять на физиологические и вегетативные процессы позволяет эффективно использовать АТ в медицине, спорте, педагогике.

Биологическая обратная связь (БОС) - это метод саморегуляции, происходящих в организме физиологических процессов, не контролирующихся сознанием посредством специальной аппаратуры. Суть метода заключается в следующем. Закрепленные на теле пациента датчики прибора БОС регистрируют параметры какойлибо системы организма и передают их на компьютер, который отображает полученные сигналы в виде визуальных или звуковых сигналов. Наблюдая за изменяющими показателями работы своего организма, пациент учиться сознательно их изменять. БОС-технология применяется во многих областях медицины (кардиологии, неврологии, психиатрии и т.д.); в спорте (для улучшения тренировочных процессов и развития стрессоустойчивости перед началом соревнований), в стресс-менеджменте (для профилактики аддиктивных состояний).

Медитацию можно назвать тренировкой мозга, цель которой состоит в овладении собственным вниманием и достижении контроля над ним. Умение концентрировать и направлять свое внимание в нужном направлении позволяет оказывать сознательное влияние на психическое и физиологическое состояние медитирующего. Известно множество медитативных методов, различающихся между собой природой объекта для фокусирования внимания: сосредоточение на словах (мантрах), на зрительных образах (янтрах), дыхании (пранаяме) и т.д. 
Медитации обладает физиологическими и психологическими эффектами. К физиологическим эффектам можно отнести возможность регулировать частоту сердечных сокращений, ритм дыхания, уровень мышечного напряжения, кожногальваническую реакцию. Психологическими эффектам медитации являются снижение тревожности, уменьшение тяги к психостимуляторам (наркотикам, табаку, алкоголю), улучшение сна, повышение настроения, усиление самоконтроля. Таким образом, медитация оказывает благоприятное воздействие на организм человека, помогая снижать артериальное давление, уменьшает мышечное напряжение и болевые ощущения, укрепляет нервную систему и помогает эффективно бороться со стрессом.

Прогрессивная релаксация изначально была создана американским врачом Э.Джекобсоном. Техника включает в себя комплекс упражнений, направленных на расслабления основных мышц тела (конечностей, туловища, плеч, шеи, головы, лица). Расслабление достигается чередованием максимального напряжения и последующего расслабления соответствующих мышц.

Прогрессивная релаксация наиболее эффективна при лечении мигреней и головных болей, а также она помогает улучшить сон, уменьшить мышечные боли и спазмы. Кроме благоприятного воздействия на физиологическое состояние, регулярная практика прогрессивной релаксации оказывает положительное влияние и на психологические состояния, например, помогает снизить тревожность, корректирует Яконцепцию. Безусловное достоинство этого метода ПСР заключается том, что для его применения не требуется специальное оборудование.

Знание методов ПСР, их особенностей и областей применения помогает выбрать наиболее эффективное средство для борьбы со стрессом, а также минимизировать его негативные последствия.

\section{$* * *$}

1. Александров, А.А. Психотерапия [Текст]: учеб. пособие / А.А. Александров. - СПб.: Питер, 2004. $240 \mathrm{c}$.

2. Гринберг, Дж. Управление стрессом. [Текст] / Дж. Гринберг; пер. с анг. Л. Гительман и М. Потаповой - 7-е изд. - СПб.: Питер, 2002. - 496 с.

3. Леонова, А.Б. Психопрофилактика стрессов [Текст] / А.Б. Леонова, А.С. Кузнецова. - М.: Изд-во Моск.ун-та, 1993. - 123 с.

4. Щербатых, Ю.В. Психология стресса и методы коррекции [Текст] / Ю.В. Щербатых. - СПб.: Питер, 2006. - $256 \mathrm{c}$.

\section{Пчелинцева Д.Г.}

Формирование нравственности у подростка к этнокультурному наследию в современных условиях на уроках иностранного языка

Академия ФСИН России

(Россия, Рязань)

doi 10.18411/spc-04-02-2019-19

idsp sciencepublic-04-02-2019-19

\section{Аннотация}

В статье автор рассматривает пути формирования интереса у подростка к изучению этнокультурных ценностей на уроках иностранного языка. Через этнокультурное образование подросток погружается в культуру и традиции народа, овладевая этнокультурными ценностями. Уроки иностранного языка вносят существенный вклад в развитие диалога культур. Они помогают изучить культурную жизнь страны через призму мировой культуры. Использование интересных материалов 
по этнокультуре на уроках иностранного языка способствует активизации познавательной деятельности учащихся и повышению качества образования.

Ключевые слова: подросток, этнокультурные ценности, иностранный язык, образование, нравственность.

\section{Abstract}

The author investigates ways of developing teenager's interest in studying ethno cultural values at foreign language lessons. Through ethno cultural education a teenager understands the culture and traditions of people, acquires ethnical cultural values. Foreign language lessons make a significant contribution to the development of the dialogue of cultures. They help us to study the country's cultural life through the prism of the world culture. Using interesting ethno cultural material at foreign language lessons helps to motivate students to study and learn more and improve the quality of education.

Key words: teenager, ethnical cultural values, foreign language, education, morality.

В современном мире процесс активной интеграции складывается в условиях глобализации, в которой многообразный мир способен существовать только в интегрированной целостности. Наше государство интенсивно включается в этот процесс и играет в нем одну из главных ролей. В связи с этим современная школа служит проводником не только отечественной культуры, но и культур зарубежных стран. Задача современного образования - подготовка всесторонне развитой личности, готовой к сотрудничеству и конструктивному общению в иноязычной среде [1.].

В настоящее время актуальным направлением является развитие нематериального культурного наследия в сфере образования. Интерес возник из-за отсутствия сформированных ценностных ориентиров национальной культуры и традиций. Сохранение нематериального культурного наследия приобретает социальное, экономическое, культурное, политическое значение. Ведь нематериальное культурное наследие - это то, что обеспечивает духовную, нравственную основу человеческого сообщества, является базовым фундаментом взаимоотношения наций и государств.

Иностранный язык - это предмет, в котором инструментом воспитания может являться система образов, воздействующая на ценностные ориентиры личности.

Одно из основных качеств успешного овладения иностранными языками в школе - это готовность признать своеобразие культуры, давшей отражение в языке, сохранив при этом основные черты и качества национального характера.

Именно иностранный язык является одним из основных предметов в школьной программе, с помощью которого формируется интерес у подростка к изучению этнокультурных ценностей.

Через этнокультурное образование подросток погружается в культуру и традиции народа, овладевая этнокультурными ценностями. Уроки иностранного языка вносят существенный вклад в развитие диалога культур. Они помогают изучить культурную жизнь страны через призму мировой культуры.

Современный урок иностранного языка нацелен на использование диалогической речи, которая содержит в себе примеры сопоставления, сравнения культур, традиций и обычаев народов. Сложившиеся веками устои, обряды и ритуалы несут в себе тот нравственный потенциал, который необходим современному подростку для развития его этнокультурной образованности.

Формирование значимости этнокультурного наследия способствует развитию национального самосознания подростка, воспитывает у него такие качества, как патриотизм, стремление к взаимопониманию, любовь к людям разных национальностей и народов. Для того чтобы лучше понять особенности англоговорящего народа, следует изучать на уроках пословицы, поговорки и скороговорки. 
У каждого народа свои пословицы, в которых содержится уникальный данного народа жизненный опыт, отношение к окружающему бытию. Мудрость пословиц помогает подростку оценить свои поступки и деяния других людей.

Целью таких уроков становится не только расширение лингвистического кругозора, но и воспитание нравственных ценностей подростка при изучении иностранного языка.

Нравственное воспитание является основной целью всякого общества. Сегодня проблемы нравственного воспитания актуальны как никогда. Ведь упущения и недостатки в этом приносят обществу невосполнимый вред. Нравственность помогает обеспечивать социальную устойчивость в отношениях человека с другими людьми и помогает ему налаживать связь с обществом.

Не менее важную роль в формировании нравственности у подростков к этнокультурному наследию является использование на уроках иностранного языка песенок, потешек, «перевертышей» и других жанров народного творчества.

Данный материал представляется подростку сокровищницей гуманистических ценностей, помогая ему приобщиться к освоению нравственного опыта предыдущего поколения.

Идеальным способом фиксации и передачи национально-культурной информации является басня. Ей принадлежит особая роль в изложении и хранении культурных представлений о нормах поведения, жизненных устоях и культурных стереотипах народов. В баснях множественный смысл передается посредством аллегории, которая порождает многозначность. На уроке иностранного языка басни могут быть применены к подходящему моменту, что является актуальным для любой разыгрываемой ситуации, и главное в этом - учесть тему.

Использование интересных материалов по этнокультуре на уроках иностранного языка способствует активизации познавательной деятельности учащихся и повышению качества образования. Улучшается также и результативность в обучении и воспитании подростка, что является важным для развития этих ценностей, от которых зависит, как будет сформирована личность подростка. Если он интересуется и любит свою культуру, то будет уважителен и к культурам других народов.

Таким образом, очевидной становится необходимость формирования у подростков этнокультуры на уроках иностранного языка с целью не только увеличения интереса к уроку, но и с целью нравственного и интеллектуального развития подростка.

$$
* * *
$$

1. Пчелинцева, Д. Г. Важность формирования коммуникативной ком-петенции у подростков в процессе изучения иностранного языка[Текст]/ Д. Г. Пчелинцева// New World. New Language. New Thinking.: сб. статей/ отв. ред. Коптелова И.Е.. - Москва : Дипломатическая академия МИД России, 2018. - C. 79-82.

\section{Садриддинов C.P. \\ Концепт психологическая защита: теоретико-практический аспект}

имени Низами ТГПУ

doi 10.18411/spc-04-02-2019-20

idsp sciencepublic-04-02-2019-20

Психологическая защита используется не только в эксквизитных случаях, а является нормальным постоянно применяемым психологическим механизмом, обеспечивающим сопротивление организмом болезни, и предотвращающим дезорганизацию психической деятельности и поведения. В психологической науке недостаточно разработаны проблемы психологической защиты. По этому поводу Е.С. Романова пишет, что в работах $50-\mathrm{x}-70-\mathrm{x}$ годов XX столетия термин «защита» 
тщательно исключался или подменялся терминами «психологический барьер», «защитные проявления личности», «защитная реакция», «смысловой барьер» и т.п. Позднее исследователи стали считать, что феномен защитных механизмов может и должен быть предметом действительно научного изучения (Б.В. Зейгарник, А.А. Налчаджян). Другие авторы избегали психоаналитической теории, изучая защиту с позиции теории деятельности или теории установки.

Термин «психологическая защита» объясняется в психологической науке с привлечением разнообразных психологических реальностей. В.И. Журбин выделил более десяти определений данного феномена через видовые, либо функциональные его характеристики: цель, результат, познавательные процессы, деятельность, регуляция и т.д. Однако каждый исследователь исходя из постановки цели исследовательской работы описывает феномены ее осуществления. По результатам сопоставительного анализа, можно провести следующую квалификацию:

- психическая деятельность, психические процессы, способы переработки информации;

- механизм адаптации, компенсации;

- стратегии межличностных, межгрупповых взаимодействий.

Основной функцией психологической защиты авторы называют «ограждение» сферы сознания от негативных, травмирующих личность переживаний; обеспечение психологической защищенности личности, которая характеризуется отсутствием повышенной тревожности, неврозов, страхов, адекватной самооценкой, реалистичным уровнем притязаний, чувством принадлежности к группе, внешней и внутренней социально-психологической адаптированостью личности к жизненной ситуации. По мнению Э. Киршбаума и А. Еремеевой, психологическая защита является не нормальным, а необычным способом разрешения ситуации и психологической регуляции поведения. Исходя из цели исследования, провели тестирование, для выявления различия между юношами и девушками по личностным особенностям.

Всем испытуемым были предложены многофакторный опросник Р.Кеттелла для определения личностных особенностей и опросник Келлермана-Плутчика для определения интенсивности защитных механизмов. Тест на определение личностных акцентуаций выполняли 237 человек, опросник на определение склонности к риску 200 человек, тест на определение типа темперамента - 323 человека, на определение потребности в поиске новых ощущений - 199 человек, на определение уровня субъективного контроля - 300 человек Исследование проводилось на три этапа: подготовка, сбор данных и их обработка.

Достоверные различия между юношами и девушками наблюдаются по факторам A, B, C, F, I, L, M, N, O, Q1, Q4 (табл. 1). Девушки имеют более высокие значения по факторам А (общительность), F (экспрессивность), N (дипломатичность) и более низкие значения по фактору С (эмоциональная устойчивость), M (мечтательность), Q1 (экспериментирование). По сравнению с юношами они имеют более высокие значения по факторам O (тревожность) и Q4 (напряженность). Данные психологические информации означает, что девушки общительны, охотно работают с людьми, им свойственна непринужденность в поведении. Они оптимистично и легко относятся к жизни, верят в удачу, мало заботится о будущем, часто демонстрируют находчивость и остроумие, получают удовольствие работы. Но в то же время они характеризуются проницательностью, разумным подходом к событиям и окружающим людям, некоторой консервативностью, устойчивостью по отношению к традиционным 
трудностям. Они могут иметь обиду на других, которая зачастую оказывается необоснованной.

Юноши же, в свою очередь, имеют высокие значения по факторам С (эмоциональная устойчивость), I (чувствительность), и низкие значения по факторам L (подозрительность), О (тревожность) и Q4 (напряженность). Юноши характеризуются как эмоционально зрелые и хорошо приспособленные. Они обычно способны достигать своих целей, осознавать требования действительности. Они не скрывают от себя собственные недостатки, не расстраиваются по пустякам и не поддаются случайным колебаниям настроений. Юноши характеризуется откровенностью, доверчивостью, благожелательностью по отношению к другим людям, терпимостью, уживчивостью; такой человек свободен от зависти, легко ладит с людьми и хорошо работает в коллективе. Как правило, в жизни они опираются на здравый смысл и логику, больше доверяют рассудку, чем чувствам. Юноши независимы, придерживаются собственной точки зрения. Они могут легко переживать жизненные неудачи, верят в себя, слабо чувствительны к оценкам окружающих. K тому же юноши отличаются расслабленностью, отсутствием видимых сильных побуждений и желаний. Они невозмутимы, спокойно относятся к неуспехам и неудачам.

Таблицุа№1.

Значимые различия личностных характеристик по полу

\begin{tabular}{|c|c|c|c|c|c|c|c|c|c|c|c|}
\hline Фактор & $\begin{array}{c}\text { Общи } \\
\text { тельност } \\
\text { ь }\end{array}$ & $\begin{array}{c}\text { Инте } \\
\text { Л } \\
\text { лект }\end{array}$ & $\begin{array}{c}\text { Эмоц } \\
\cdot \\
\text { усто } \\
\text { й } \\
\text { чИ- } \\
\text { вость }\end{array}$ & $\begin{array}{c}\text { Экс- } \\
\text { прес- } \\
\text { сив- } \\
\text { ност } \\
\text { ь }\end{array}$ & $\begin{array}{c}\text { Чув- } \\
\text { стви- } \\
\text { тель- } \\
\text { ност } \\
\text { ь }\end{array}$ & $\begin{array}{c}\text { Подо } \\
\mathbf{3} \\
\text { ри- } \\
\text { тель- } \\
\text { ност } \\
\text { ь }\end{array}$ & $\begin{array}{l}\text { Мечт } \\
\text { а } \\
\text { тель- } \\
\text { ность }\end{array}$ & $\begin{array}{c}\text { Дип- } \\
\text { лома } \\
\text {-тич } \\
\text { ност } \\
\text { ь }\end{array}$ & $\begin{array}{c}\text { Tре- } \\
\text { вож- } \\
\text { ност } \\
\text { b }\end{array}$ & $\begin{array}{c}\text { Эксп } \\
\text { е } \\
\text { ри- } \\
\text { мен- } \\
\text { тиро- } \\
\text { вани } \\
\text { е }\end{array}$ & $\begin{array}{c}\text { Напр } \\
\text { я } \\
\text { жен- } \\
\text { ность }\end{array}$ \\
\hline $\begin{array}{c}\text { Обозна } \\
\text { ч. }\end{array}$ & A & B & C & $\mathrm{F}$ & I & $\mathrm{L}$ & M & $\mathrm{N}$ & $\mathrm{O}$ & Q1 & Q4 \\
\hline $\begin{array}{c}\text { Девуш- } \\
\text { ки }\end{array}$ & 13.09 & 8.76 & 14.80 & 16.69 & 12.37 & 11.84 & 9.67 & 10.25 & 12.94 & 10.03 & 14.44 \\
\hline Юноши & 10.95 & 7.76 & 1552 & 15,15 & 8.02 & 10.6 & 10.5 & 9.08 & 10.82 & 10.79 & 12.15 \\
\hline $\mathrm{t}$ & 5.4 & 3.28 & -2.21 & 3.4 & 10.94 & 2.9 & -2.15 & 3.5 & 4.4 & -2.31 & 4.28 \\
\hline $\mathrm{p}$ & 0.0001 & $\begin{array}{c}0.001 \\
1\end{array}$ & $\begin{array}{c}0.027 \\
8\end{array}$ & $\begin{array}{c}0.000 \\
8\end{array}$ & $\begin{array}{c}0.000 \\
1\end{array}$ & $\begin{array}{c}0.003 \\
8\end{array}$ & $\begin{array}{c}0.032 \\
4\end{array}$ & $\begin{array}{c}0.000 \\
5\end{array}$ & $\begin{array}{c}0.000 \\
1\end{array}$ & $\begin{array}{c}0.021 \\
6\end{array}$ & $\begin{array}{c}0.000 \\
1\end{array}$ \\
\hline
\end{tabular}

Обнаружены различия между юношами и девушками по другим психологическим характеристикам.

Таблийа №2.

Значимые различия типов личностных акиентуаций

\begin{tabular}{|c|c|c|c|c|c|c|}
\hline $\begin{array}{c}\text { Акцентуа- } \\
\text { ция }\end{array}$ & $\begin{array}{c}\text { Возбу- } \\
\text { димый } \\
\text { тип }\end{array}$ & $\begin{array}{c}\text { Эмотив- } \\
\text { ный тип }\end{array}$ & $\begin{array}{c}\text { Тревож- } \\
\text { ный тип }\end{array}$ & $\begin{array}{c}\text { Цикло- } \\
\text { тимный } \\
\text { тип }\end{array}$ & $\begin{array}{c}\text { Демонст- } \\
\text { ративный } \\
\text { тип }\end{array}$ & $\begin{array}{c}\text { Экзаль- } \\
\text { тиро-- } \\
\text { ванный } \\
\text { тип }\end{array}$ \\
\hline Девушки & 14.87 & 16.90 & 12.17 & 16.73 & 15.30 & 16.65 \\
\hline Юноши & 13.01 & 11.33 & 8.20 & 13.97 & 12.49 & 13.66 \\
\hline$t$ & 3.33 & 7.79 & 5.24 & 4.01 & 4.76 & 4.28 \\
\hline$p$ & 0.001 & 0.0001 & 0.0001 & 0.0001 & 0.0001 & 0.0001 \\
\hline
\end{tabular}

По результатам эмпирического исследования гендерные различия обнаружены в уровне выраженности 6 типов акцентуаций из 10 (табл. 2). Все различия наблюдаются на уровне значимости $\mathrm{p}<0.01$. Выявлены различия по таким типам акцентуаций, как возбудимый, эмотивный, тревожный, циклотимный, демонстративный и 
экзальтированный. По всем этим типам акцентуаций девушки имеют более высокие показатели, чем юноши. Почти у трети (33.8\%) девушек выраженность акцентуации эмотивного типа больше 18, а чуть меньше половины всех девушек (42.3\%) имеют выраженность акцентуации циклотимного типа больше 18. Основываясь на этих различиях можно охарактеризовать девушек следующим образом. Для них характерны эмоциональность, чувствительность, тревожность, боязливость. Наиболее сильно выраженная черта - гуманность, сопереживание другим людям или животным, отзывчивость, мягкосердечность, сорадование чужим успехам.

Они впечатлительны, им свойственна высокая контактность. Они могут демонстрировать смену гипертимных и дистимных состояний. Им свойственны частые периодические смены настроения, а также зависимость от внешних событий. Радостные события вызывают у них картины гипертимии: жажда деятельности, повышенная говорливость, скачка идей; печальные - подавленность, замедленность реакций и мышления, так же часто меняется их манера общения с окружающими людьми. Юноши же имеют низкие показатели по тревожному типу акцентуации. 80,1\% юношей имеют выраженность акцентуации тревожного типа меньше 12.

В результате обработки полученных данных обнаружены различия между юношами и девушками в уровне психотизма $(\mathrm{p}<0.01)$ и нейротизма $(\mathrm{p}<0.01)$. У девушек больше выражен нейротизм $(\mathrm{M}=14.6)$, что характеризует их как неустойчивых, склонных к быстрой смене настроений (лабильности), чувству виновности и беспокойства, озабоченности, депрессивным реакциям, рассеянности внимания, неустойчивости в стрессовых ситуациях. Нейротизму соответствует эмоциональность, импульсивность; неровность в контактах с людьми, изменчивость интересов, неуверенность в себе, выраженная чувствительность, впечатлительность, склонность к раздражительности. Юноши $(\mathrm{M}=7.85)$ больше, чем девушки $(\mathrm{M}=5.99)$, склонны к асоциальному поведению, неадекватности эмоциональной реакции, высокой конфликтности.

В ходе исследования выявлено, что психологическая защита представляет собой интегрированную структуру. Механизмы психологической защиты редко работают обособленно, чаще один механизм поддерживает работу другого. Нам удалось составить психологические портреты юношей и девушек по активному защитному механизму. Следует отметить, что защита девушек больше связана с интернальностью, а также имеет более ситуативный, проблемный характер, чем у юношей.

$$
* * *
$$

1. Ананьев Б.Г. О проблеме современного человекознания. - М.: Наука, 1977. - 380 с.

2. Журбин В.И. Понятие психологической защиты в концепциях 3. Фрейда и К. Роджерса // Вопросы психологии. - 1990. - №4. - С.14-22.

3. Зейгарник Б.В., Холмогорова А.Б., Мазур Е.С. Саморегуляция поведения в норме и патологии // Психол. журнал. - 1989. - №2. - С. 122-131.

4. Зейгарник Б.В., Холмогорова А.Б., Мазур Е.С. Саморегуляция поведения в норме и патологии // Психол. журнал. - 1989. - №2. - С. 122-131.

5. Киршбаум Э. И., Еремеева А. И. Психологическая защита. - М.: Смысл, 2000. - 181 с.

6. Налчаджян А.А. Психологические защитные механизмы // Самосознание и защитные механизмы личности. - Самара, 2003. - С. 395-481. 


\section{Dля заметок}




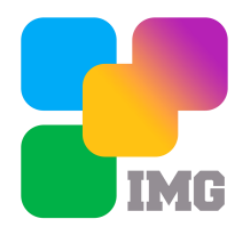

Научное издание

\section{«Научные тенденции: Педагогика и психология»}

Сборник научных трудов, по материалам

XXI международной научно-практической конференции

4 февраля 2019 г.

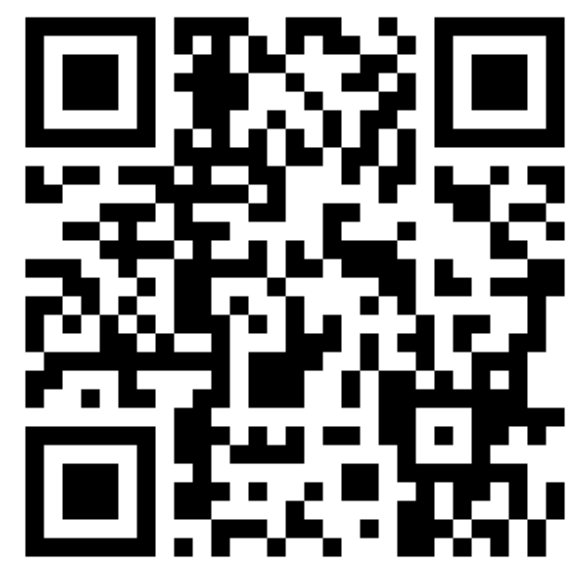

SPLN 001-000001-0392-PP

Подписано в печать 24.02.2019. Тираж 400 экз. Формат.60х841/16. Объем уч.-изд. л.3,9

Бумага офсетная. Печать оперативная.

Отпечатано в типографии НИЦ «Л-Журнал»

Главный редактор: Иванов Владислав Вячеславович 